\title{
WATER-RESOURCES ACTIVITIES OF THE
}

\section{U.S. GEOLOGICAL SURVEY IN UTAH,}

OCTOBER 1, 1993, TO SEPTEMBER 30, 1994

Compiled by Ellen E. Hardy and Stefanie L. Dragos

U.S. GEOLOGICAL SURVEY

Open-File Report 96-102 


\title{
Message from the District Chief
}

The U.S. Geological Survey, Water Resources Division, is entering its 105th year of activities in Utah. As Utah's demand for water has increased, so has the need for quantitative, unbiased water-resources data and interpretive studies. The Utah District program is designed to provide this information and help the Water Resources Division meet its goal of assessing the quantity and quality of the Nation's water resources.

Total funding for the Utah District during fiscal year 1994 was about $\$ 5.0$ million, which is the same amount as for fiscal year 1993. During fiscal year 1994, the Utah District initiated a National Water Quality Assessment (NAWQA) study in the Great Salt Lake drainage basin. Funding for the NAWQA program during the first year was about $\$ 0.2$ million but is expected to increase to about $\$ 1.5$ million during the coming years and create a significant increase in the overall District program.

The most significant hydrologic event of the 1994 water year was the return of drought conditions throughout Utah. Precipitation was less than normal throughout most of the State and much less than normal in some areas. Precipitation at 8 of 11 selected recording stations was less than normal. Streamflow at seven index gaging stations ranged from 59 to 79 percent of the long-term mean flow. Spring runoff was deficient because of less-than-normal snowpack, and streams reached baseflow conditions in May or June instead of July or August as is normal. Reservoir storage was adequate because of a larger-than-normal carryover from the wetter-than-normal 1993 water year.

Monitoring hydrologic conditions during fiscal year 1994 presented special challenges and illustrated the usefulness of long-term records. As streamflow decreased, water managers and decision makers required accurate and timely discharge data to ensure that each user received the appropriate amount of available water. The longterm records were useful in placing the current drought into historical perspective and provided a basis for worstcase-scenario planning.

The future promises the continued challenge of helping local, State, and Federal agencies meet their waterresources information needs. I look forward to another active year in which U.S. Geological Survey water-resources investigations and data collection help meet these needs.

\author{
H. Lee Case III \\ District Chief \\ U.S. Geological Survey, Water Resources Division \\ Salt Lake City, Utah
}




\section{CONTENTS}

Introduction

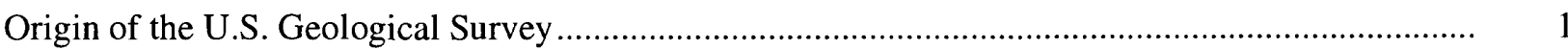

Mission of the U.S. Geological Survey, Water Resources Division ............................................... 2

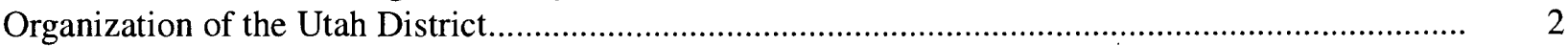

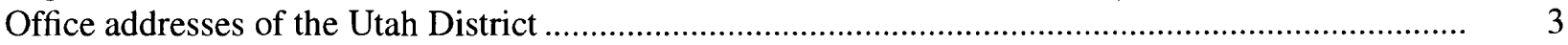

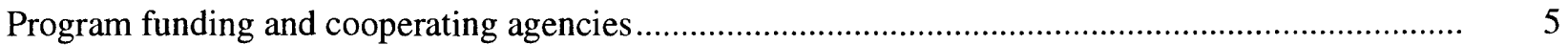

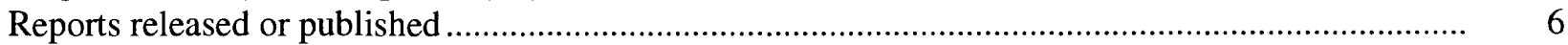

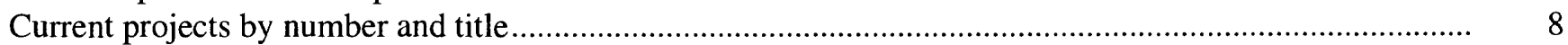

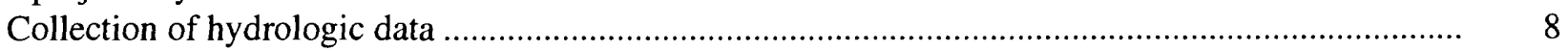

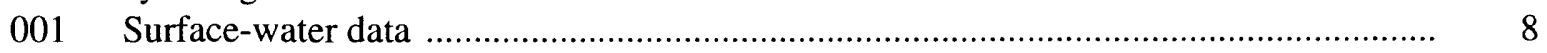

002 Ground-water data and ground-water conditions in Utah ..................................... 11

003, 004, and 005 Water-quality, fluvial-sediment, and precipitation data ........................... 13

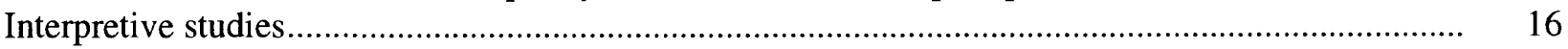

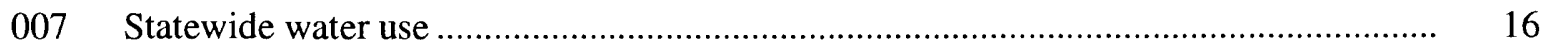

196 Ground water in southern Utah and Goshen Valleys, Utah County, Utah..................... 18

204 Identification and quantification of mechanisms causing decreasing salt-crust thickness, Bonneville Salt Flats, western Utah ........................................................ 19

205 Ground-water flow and solute migration in Salt Lake Valley, Utah............................ 21

211 Recharge to basin-fill aquifers from irrigation, southwestern Utah ............................. 23

213 Hydrologic study of lower Ashley Creek, Uintah County, and monitoring for remedial activities related to selenium contaminants, middle Green River basin, Utah ............... 24

218 Ground water in Juab Valley, Juab County, Utah ....................................................... 25

219 Hydrologic reconnaissance of the Beaver Dam Wash area of the Virgin River basin, Washington County, Utah, Mohave County, Arizona, and Lincoln County, Nevada .... $\quad 26$

220 Data synthesis of results of investigations conducted under the Department of the Interior National Irrigation Water-Quality Program.................................................... 27

221 Water resources of Synderville basin, Park City, and surrounding communities, Summit County, Utah

222 Using multivariate statistics and pattern-recognition techniques to define possible migration pathways of saline water into fresh ground water, Aneth area, Utah .............

224 National Water Quality Assessment (NAWQA) for Great Salt Lake river basins,

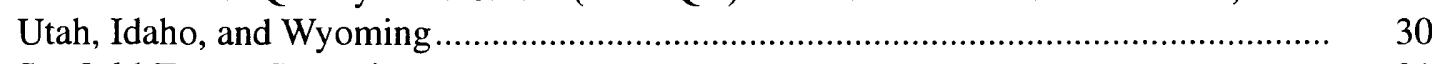

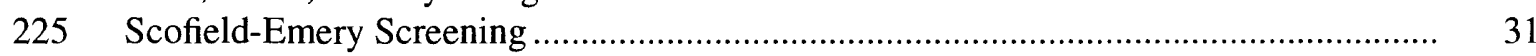

226 Application of topographically distributed energy-balance snowmelt-runoff model to a mountain basin with cold, low-density snowcover under varying climate conditions.

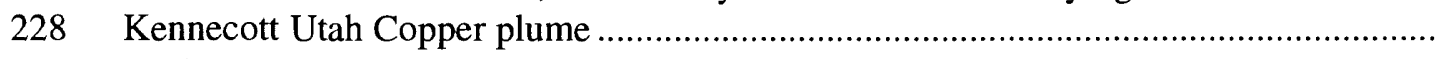

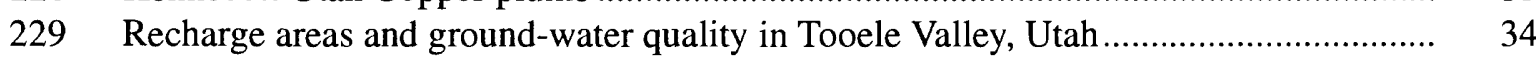

References cited

\section{ILLUSTRATIONS}

1-6. Maps of Utah showing:

1. Location of U.S. Geological Survey, Water Resources Division, offices and general areas of responsibility

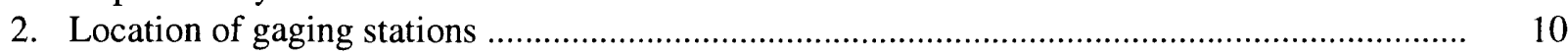

3. Location of observation wells in which water levels were measured .................................... 12

4. Location of surface-water-quality stations ............................................................... 14

5. Location of observation wells where water samples were collected for monitoring water quality

6. Location of interpretive studies 


\title{
WATER-RESOURCES ACTIVITIES BY THE U.S. GEOLOGICAL SURVEY IN UTAH, OCTOBER 1, 1993, TO SEPTEMBER 30, 1994
}

\author{
Compiled by Ellen E. Hardy and Stefanie L. Dragos
}

\section{INTRODUCTION}

This report contains summaries of the progress of water-resources studies in Utah by the U.S. Geological Survey, Water Resources Division, Utah District, from October 1, 1993, to September 30, 1994. The water-resources program in Utah during this period consisted of 21 projects; a discussion of each project is presented in the main body of this report.

The following sections outline the origin of the U.S. Geological Survey, the basic mission of the Water Resources Division, the organizational structure of the Utah District, office addresses of the Utah District, the distribution of District funding in terms of source of funds and type of activity funded, and the agencies with which the District cooperates. The last part of the introduction is a list of reports produced by the District from October 1993 to September 1994.

\section{Origin of the U.S. Geological Survey}

The U.S. Geological Survey was established by an act of Congress on March 3, 1879, to provide a perranent Federal agency to conduct the systematic and scientific "classification of the public lands, and examination of the geologic structure, mineral resources, and products of national domain." An integral part of that original mission includes publishing and disseminating the earth-science information needed to understand, to plan the use of, and to manage the Nation's energy, land, mineral, and water resources.

Since 1879, the research and fact-finding role of the U.S. Geological Survey has grown and been modified to meet the changing needs of the Nation it serves. As part of that evolution, the U.S. Geological Survey has b:come the Federal Government's largest earth-science research agency, the Nation's largest civilian map-making agency, the primary source of data on the Nation's surface- and ground-water resources, and the employer of the largest number of professional earth scientists. Today's programs serve a diversity of needs and users. Programs include:

- Conducting detailed assessments of the energy and mineral potential of the Nation's land and offshore areas.

- Investigating and issuing warnings of earthquakes, volcanic eruptions, landslides, and other geologic and hydrologic hazards.

- Conducting research on the geologic structure of the Nation.

- Studying the geologic features, structure, processes, and history of the other planets of our solar system.

- Conducting topographic surveys of the Nation and preparing topographic and thematic maps and related cartographic products.

- Developing and producing digital cartographic data bases and products.

- Collecting data on a routine basis to determine the quantity, quality, and use of surface and ground witer.

- Conducting water-resource appraisals in order to describe the consequences of alternative plans for developing land and water resources.

- Conducting research in hydraulics and hydrology, and coordinating all Federal water-data acquisition. 
- Using remotely sensed data to develop new cartographic, geologic, and hydrologic research techniques for natural-resources planning and management.

- Providing earth-science information through an extensive publication program and a network of public access points.

Along with its continuing commitment to meet the growing and changing earth-science needs of the $I^{\top}$ ation, the U.S. Geological Survey remains dedicated to its original mission to collect, analyze, interpret, publish, and disseminate information about the natural resources of the Nation-providing "Earth Science in the Public Service."

\section{Mission of the U.S. Geological Survey, Water Resources Division}

The mission of the Water Resources Division, which supports the overall mission of the U.S. Department of the Interior and the U.S. Geological Survey, is to provide the hydrologic information and understanding needed for the best use and management of the Nation's water resources for the benefit of the people of the United States.

To accomplish its mission, the Water Resources Division, in cooperation with State and local governments and other Federal agencies:

- Systematically collects data needed for the continuing determination and evaluation of the quantity, quality, and use of the Nation's water resources.

- Conducts analytical and interpretive water-resources appraisals to describe the occurrence, availability, and physical, chemical, and biological characteristics of surface and ground water and their interrelation.

- Conducts supportive basic and problem-oriented research in hydraulics, hydrology, and related fields of science and engineering to improve the basis for field investigations and measurement techniques and to understand hydrologic systems sufficiently well to predict quantitatively their response to stress, eitl ar natural or manmade.

- Disseminates water data and the results of investigations and research through reports, maps, computerized information services, and other forms of public releases.

- Coordinates the activities of all Federal agencies in the acquisition of certain water data.

- Provides scientific and technical assistance in hydrologic fields to State, local, and other Federal agen ries, to licensees of the Federal Energy Regulatory Commission, and, on behalf of the U.S. Department of State, to international agencies.

- Acquires, develops, and disseminates information on water-related natural hazards such as droughts, floods, landslides, land subsidence, mudflows, and volcanoes.

- Administers the provisions of the Water Resources Research Act of 1984 that include the programs of the State Water Resources Research Institutes and the Research Grants and Contracts.

- Supports the provisions of the National Environmental Policy Act of 1969 and manages Geological Survey conduct of natural-resources surveys in response to the Comprehensive Environmental Response, Compensation, and Liability Act (Superfund Act) of 1980.

Authority for carrying out this mission is derived from legislation of 1879 , which created the U.S. Geological Survey, and legislation of 1888 and 1894, which provided for gaging of streams and determining the Nation's water supply. Congressional appropriations have been made annually since 1894 for gaging streams and performing other functions relating to water resources. In 1964, the U.S. Geological Survey's mission was broadened to include the role of lead agency in the coordination of the activities of all Federal agencies in the acquisition of certain water data. This responsibility was assigned to the Department of the Interior by the Office of Management and Budget Circular A-67.

\section{Organization of the Utah District}

The Utah District of the Water Resources Division is organized into five operating sections under the $\mathrm{L}$ : strict Chief (see organization chart). Water-resources projects are done by the Investigations Section (primarily interpretive studies) and Hydrologic Surveillance Section (primarily collection of hydrologic data). Responsibility fcr each 
project is assigned to a project chief. Support for project work is supplied by the Publications Section, which processes and illustrates reports, and the Computer Services and Administrative Services Sections. The Utah District consists of the District Office in Salt Lake City and Field Headquarters in Salt Lake City, Moab, and Cedar City. The locations of these offices and their areas of responsibility are shown in figure 1.

\section{Utah District Organization}

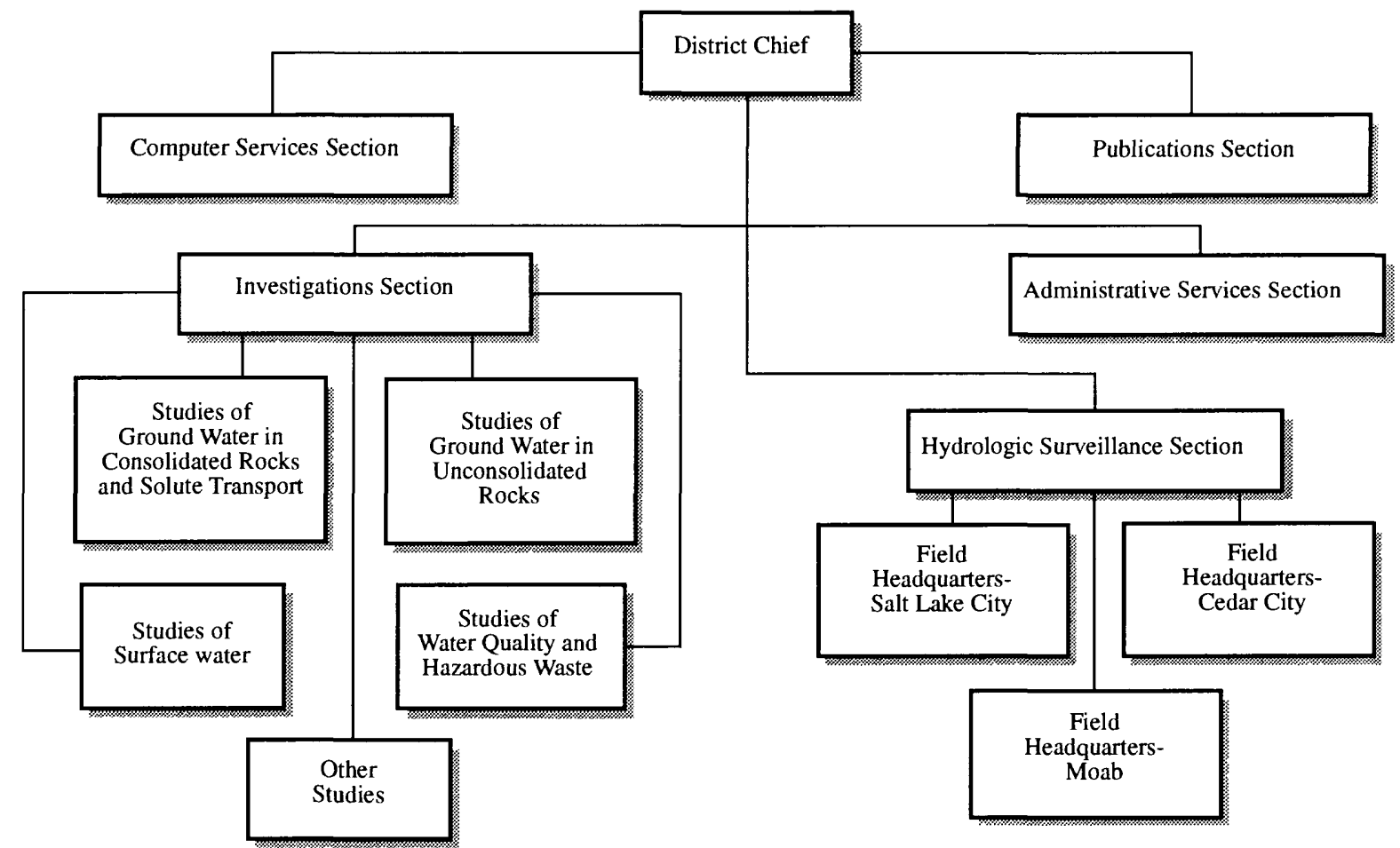

\section{Office Addresses of the Utah District}

Inquiries regarding projects described in this report may be directed to the District Office or the office in which the work originated.
District Office
U.S. Geological Survey
and Salt Lake City
Water Resources Division
Moab Field Headquarters
(801) 259-5495
U.S. Geological Survey
Field Headquarters
Room 1016 Administration
Water Resources Division
(801) 975-3350
Building
121 West 200 Soutl
P.O. Box 490
1745 West 1700 South
Moab, Utah 84532
Salt Lake City, Utah 84104
Cedar City Field
Headquarters
U.S. Geological Survey
Water Resources Division
(801) 586-4543
82 North 100 East
Room 202
P.O. Box 1066
Cedar City, Utah 84720 


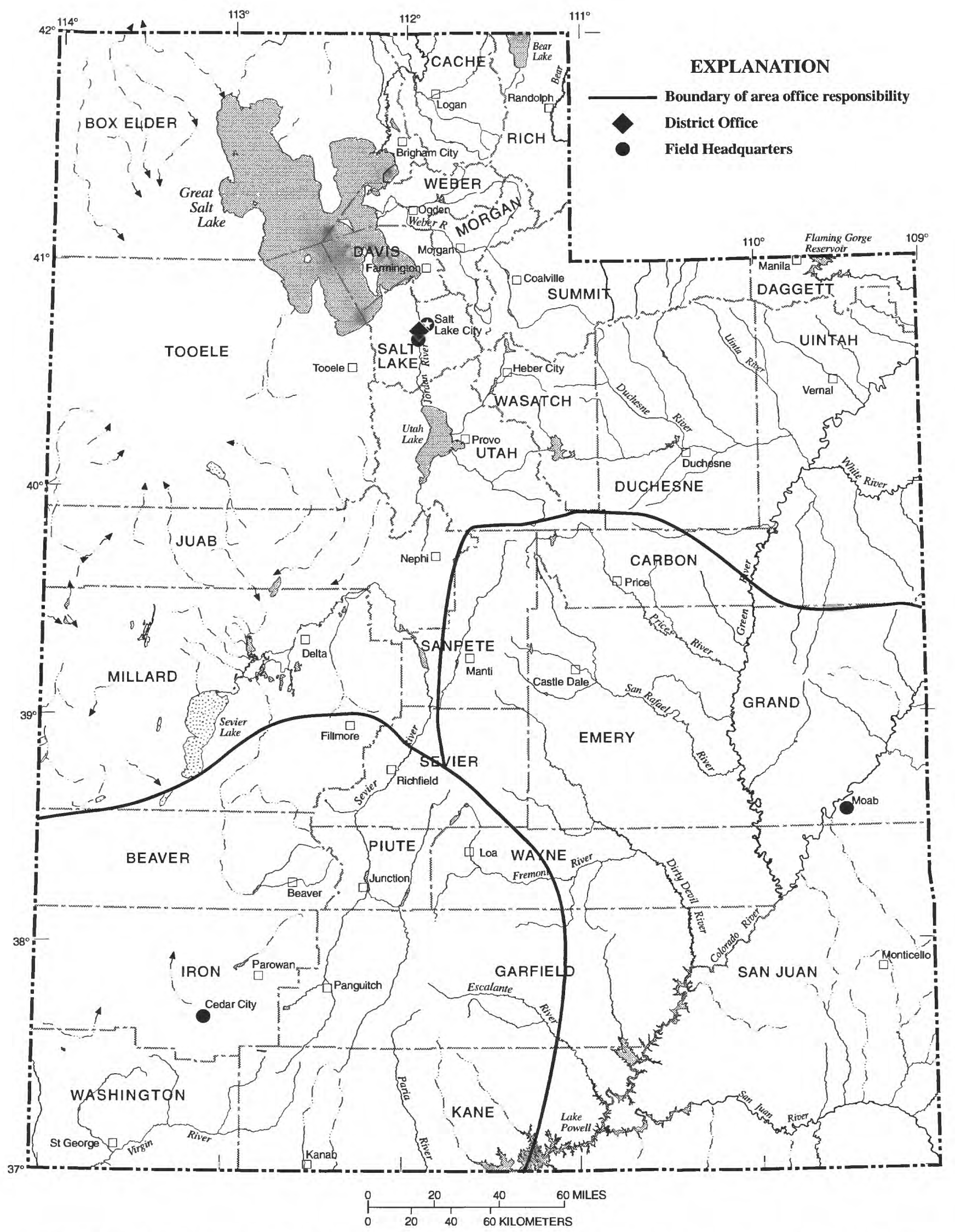

Figure 1. Location of U.S. Geological Survey, Water Resources Division, offices and general areas of responsibility. 


\section{Program Funding and Cooperating Agencies}

Funds to support water-resources work by the Utah District are from three sources. Cooperative-program funds and services are provided from State and local government agencies and generally are matched by Federal funds on a 50-50 basis. Funds transferred from other Federal agencies (OFA) are part of the OFA Program, and funds appropriated directly to the U.S. Geological Survey by Congress are part of the Federal Program. In fiscal year 1994, total financial support from these programs for the Utah District was about $\$ 5.0$ million. The distribution of funds among the three sources is:

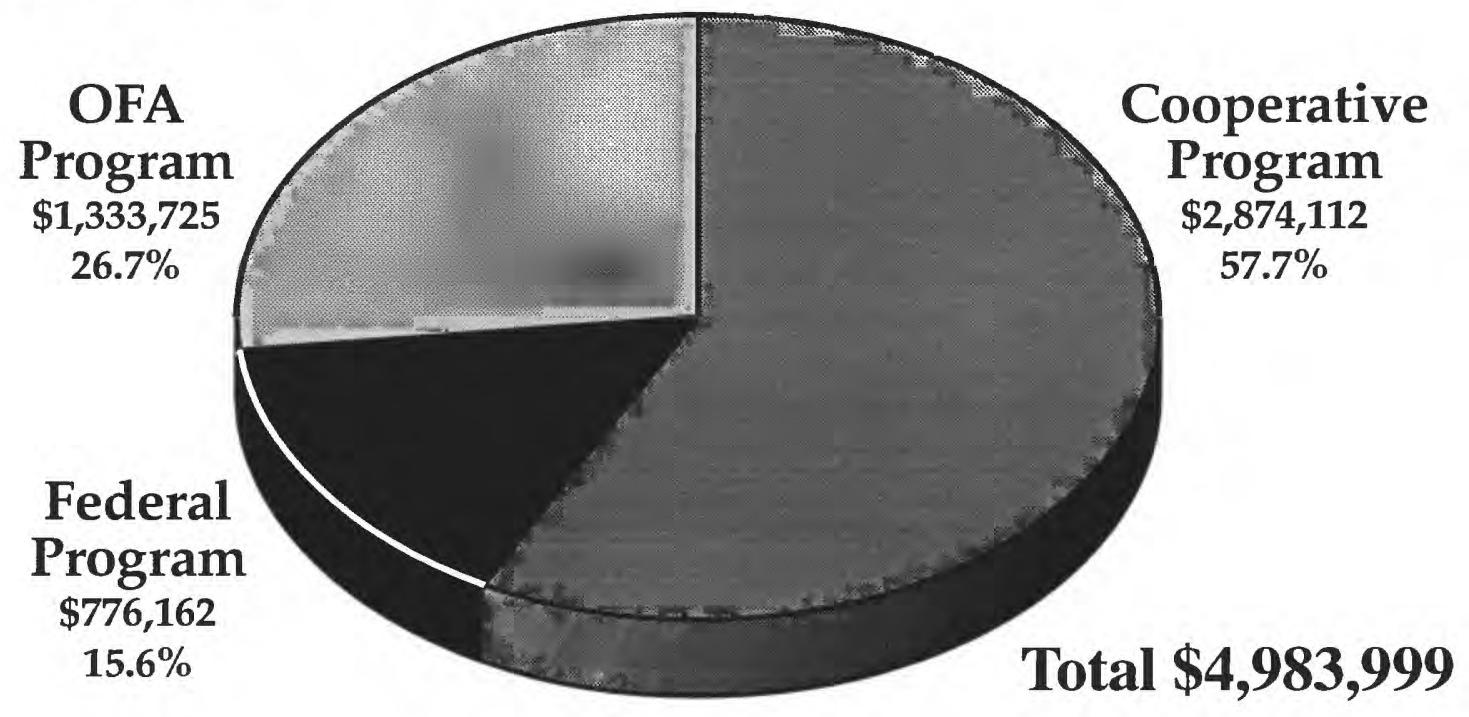

In fiscal year 1994, the Utah District pursued three broad categories of studies: (1) collection of hydrologic data, (2) interpretive studies and areal appraisals, and (3) research projects. About 53 percent of the program was for collection of hydrologic data, about 43 percent was for interpretive studies and appraisals, and about 3 percent was for research projects. These studies provide water managers and planners with information about the availability and quality of Utah's water resources. The distribution of funds among the three categories is:

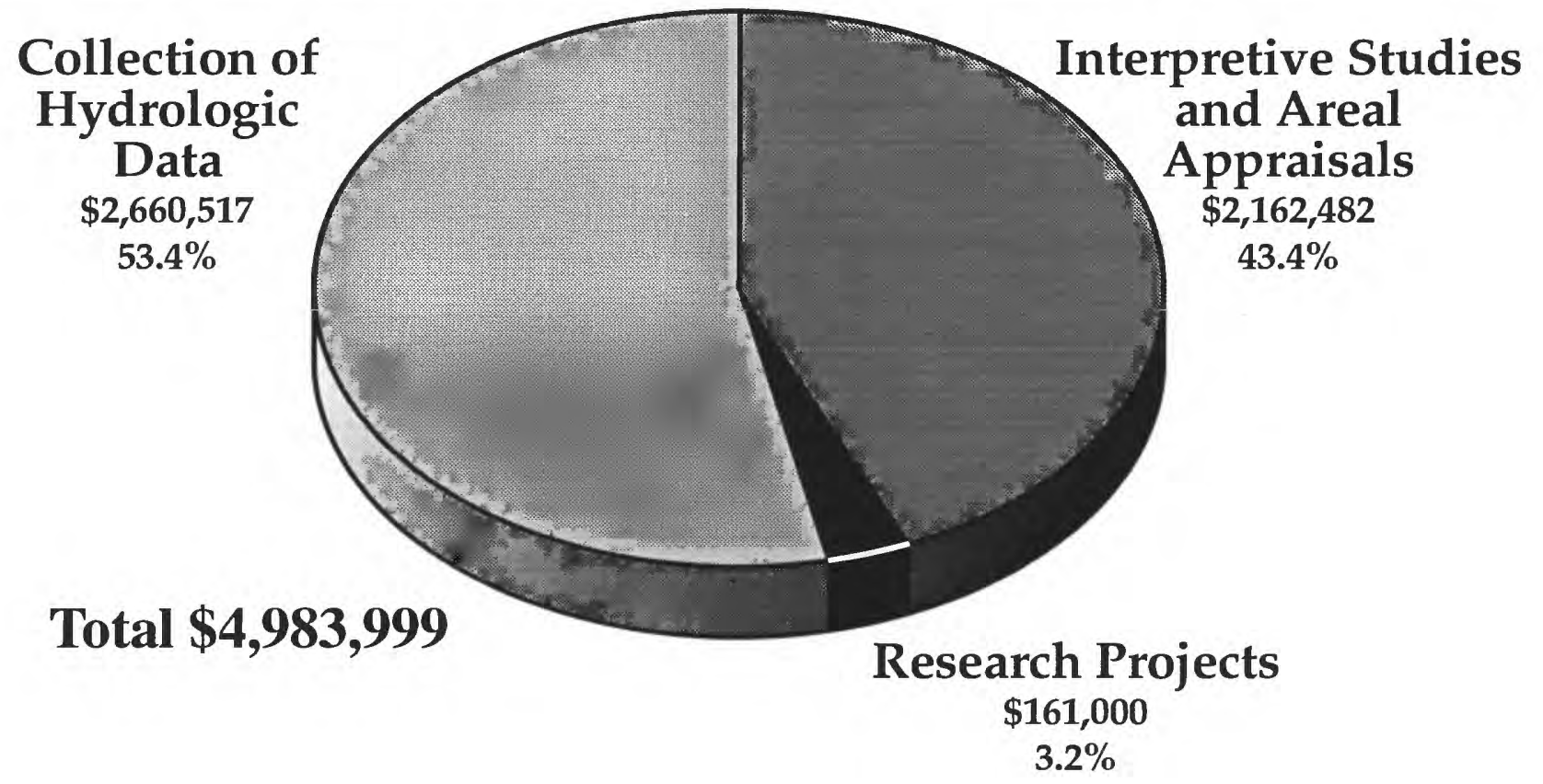


From October 1, 1993, to September 30, 1994, the cooperating agencies for District projects were:

\section{State Agencies}

Arizona Department of Water Resources

Nevada Department of Conservation and Natural Resources

Division of Water Resources

Utah Department of Environmental Quality

Division of Water Quality

Utah Department of Natural Resources

Division of Oil, Gas, and Mining

Division of Water Resources

Division of Water Rights

Geological Survey

\section{Local Agencies}

Bear River Commission

Central Utah Water Conservancy District

East Juab County Water Conservancy District

Ogden River Water Users Association

Salt Lake County Division of Flood Control and Water Quality

Tooele County

Weber Basin Water Conservancy District

Weber River Water Users Association

\section{Federal Agencies}

Bureau of Land Management

Bureau of Reclamation

National Park Service

U.S. Air Force

U.S. Department of the Interior

National Irrigation Water-Quality Program

U.S. Environmental Protection Agency

U.S. Fish and Wildlife Service

\section{Reports Released or Published} locations:

Reports prepared by or in cooperation with the Utah District can be obtained or inspected at the following

Utah District Office: U.S. Geological Survey Open-File Reports, Water-Resources Investigations Reports, Hydrologic-Data Reports, and Water-Data Reports; Utah Department of Natural Resources Technical Publications, and Cooperative Investigations Reports.

U.S. Geological Survey Earth Science Information Center: U.S. Geological Survey Water-Supply Papers, Professional Papers, Circulars, and Hydrologic Investigations Atlases.

Utah Department of Natural Resources, Division of Water Rights: Utah Department of Natural Rerources Technical Publications and U.S. Geological Survey Water Circulars, Hydrologic-Data Reports, and Water-Use Reports.

Utah Department of Natural Resources, Division of Water Resources: Utah Department of Natural Resources Cooperative Investigations Reports. 
The following reports were published during October 1, 1993, to September 30, 1994:

Allen, D.V., Garrett, R.B., and others, 1994, Ground-water conditions in Utah, spring of 1994: Utah Department of Natural Resources Cooperative Investigations Report Number 34, 89 p.

Baskin, R.L., Spangler, L.E., and Holmes, W.F., 1994, Physical characteristics and quality of water from salected springs and wells in the Lincoln Point-Bird Island area, Utah Lake, Utah: U.S. Geological Survey WaterResources Investigations Report 93-4219, 59 p.

Cordy, G.E., Seiler, R.L., and Stolp, B.J., 1994, Hydrology of the L.C. Holding coal-lease tract and adjacent areas, southwestern Utah, and potential effects of coal mining: U.S. Geological Survey Water-Resources Investigations Report 91-4111,84 p.

Freethey, G.W., 1994, Maps summarizing geohydrologic information in an area of salt-water disposal, eastern Altamont-Bluebell Petroleum Field, Uinta Basin, Utah: U.S. Geological Survey Water-Resources Investigations Report 92-4043.

Freethey, G.W., Spangler, L.E., and Monheiser, W.J., 1994, Determination of hydrologic properties needed to calculate average linear velocity and travel time of ground water in the principal aquifer underlying the southeastern part of Salt Lake Valley, Utah: U.S. Geological Survey Water-Resources Investigations Refort 924085, $30 \mathrm{p}$.

Hardy, E.E., and Dragos, S.L., 1994, Bibliography of U.S. Geological Survey water-resources reports fo- Utah, 1886-1993: U.S. Geological Survey Open-File Report 94-309, 74 p.

Hardy, E.E., and Gates, J.S., 1994, Water-resources activities in Utah by the U.S. Geological Survey, October 1, 1991, to September 30, 1992: U.S. Geological Survey Open-File Report 93-467, 42 p.

Kariya, K.A., Roark, D.M., and Hanson, K.M., 1994, Hydrology of Cache Valley, Cache County, Utah, and adjacent part of Idaho, with emphasis on simulation of ground-water flow: Utah Department of Natural Resources Technical Publication No. 108, 120 p.

ReMillard, M.D., and others, 1994, Water resources data for Utah, water year 1993: U.S. Geological Survey WaterData Report UT-93-1.

Stolp, B.J., 1994, Hydrology and potential for ground-water development in southeastern Tooele Valley ant adjacent areas in the Oquirrh Mountains, Tooele County, Utah: Utah Department of Natural Resources Technical Publication No. 107, 67 p.

Thiros, S.A., and Brothers, W.C., 1993, Ground-water hydrology of the Upper Sevier River basin, south-central Utah, and simulation of ground-water flow in the valley-fill aquifer in Panguitch Valley: Utah Department of Natural Resources Technical Publication No. 102, 121 p.

Wold, S.R., and Waddell, K.M., 1994, Salt budget for West Pond, Utah, April 1987 to June 1989: U.S. Geological Survey Water-Resources Investigations Report 93-4028, 30 p. 


\section{CURRENT PROJECTS BY NUMBER AND TITLE}

\section{Collection of Hydrologic Data}

\section{Surface-Water Data}

Project Number: UT-00-001

Cooperating Agencies: Bureau of Reclamation; National Park Service; Utah Division of Water Rights; Utah Division of Water Resources; Utah Geological Survey; Bear River Commission; Weber Basin Water Conservancy District; Salt Lake County Division of Flood Control and Water Quality; Weber River Water Users Association; Ogden River Water Users Association; and other local water agencies

Staff: $\quad$ L.R. Herbert, Hydrologic Technician, Project Chief (part time)

Other District personnel as assigned

Period of Project: Continuing

Problem: Information on surface water is needed for the planning, design, operation, and management of Utah's surface-water resources and for warning of hazards related to surface water. This information is used in water-related fields such as water supply, hydroelectric power generation, irrigation, flood control, bridge and culvert design, wildlife management, pollution abatement, flood-plain management, and water-resources development. To provide this information, an appropriate data base on discharge of streams and contents and stages of reservoirs and lakes is necessary.

Objectives: To obtain data on stream discharge and reservoir and lake contents and stages at selected sites throughout Utah.

Approach: Standard methods for the operation and maintenance of streamflow-gaging stations and for the computation, computer storage, and publication of the data are used.

Progress: Data collection and computation necessary for the publication of discharge records for 180 streamflowgaging stations and contents and stage records for 17 reservoir- and 3 lake-stage stations continued during $\mathrm{tl} \cdot \%$ year. In addition, streamflow data were collected at seven partial-record sites. Also, periodic measurements were made of flow of water through the breach in the causeway across Great Salt Lake. The locations of the gaging stations and station numbers are shown in figure 2. Data collected at these stations, as well as larger-scale maps showing station locations, are presented in the series of reports entitled "Water resources data for Utah," U.S. Geological Survey Water-Data Reports. The stations are classified as follows:

\section{Number of stations}

\section{Discharge}

Current use

Hydrologic data for planning and design

Benchmark for long-term trends

Fourteen streamflow-gaging stations were discontinued as of September 30, 1994. These were:

09274900 West Fork Duchesne River below Vat diversion near Hanna

09275500 West Fork Duchesne River near Hanna

09277800 Rock Creek below Stillwater Dam

09279100 Rock Creek near Talmage

09285000 Strawberry River near Soldier Spring

09285900 Strawberry River at Pinnacles near Fruitland

09286700 Currant Creek below Dam near Fruitland

09288395 Starvation Reservoir near Duchesne 
09288400 Strawberry River below Starvation Reservoir

09405490 North Fork Virgin River above Big Bend near Springdale

09414900 Beaver Dam Wash at mouth near Littlefield, Nevada

10155100 Provo River below Jordanelle Dam near Heber

10172795 Box Elder Wash near Grantsville

10215700 Oak Creek near Spring City

One streamflow-gaging station was established as of September 30, 1994, for use in fiscal year 1995 :

09403690 Johnson Wash above Flood Canyon near Kanab

Plans for Next Year: Continue operation of network. Prepare 1995 water-year records for publication. Continue monitoring flow through the breach in the Great Salt Lake causeway. Complete report on floods in the Great Basin during 1983-84. Complete report on surface-water reconnaissance of the Sevier River basin upstream from Sevier Bridge Reservoir. Study a selected reach of the Virgin River for gains and losses and publish report.

Reports:

ReMillard, M.D., and others, 1994, Water resources data for Utah, water year 1993: U.S. Geological Survey WaterData Report UT-93-1. 


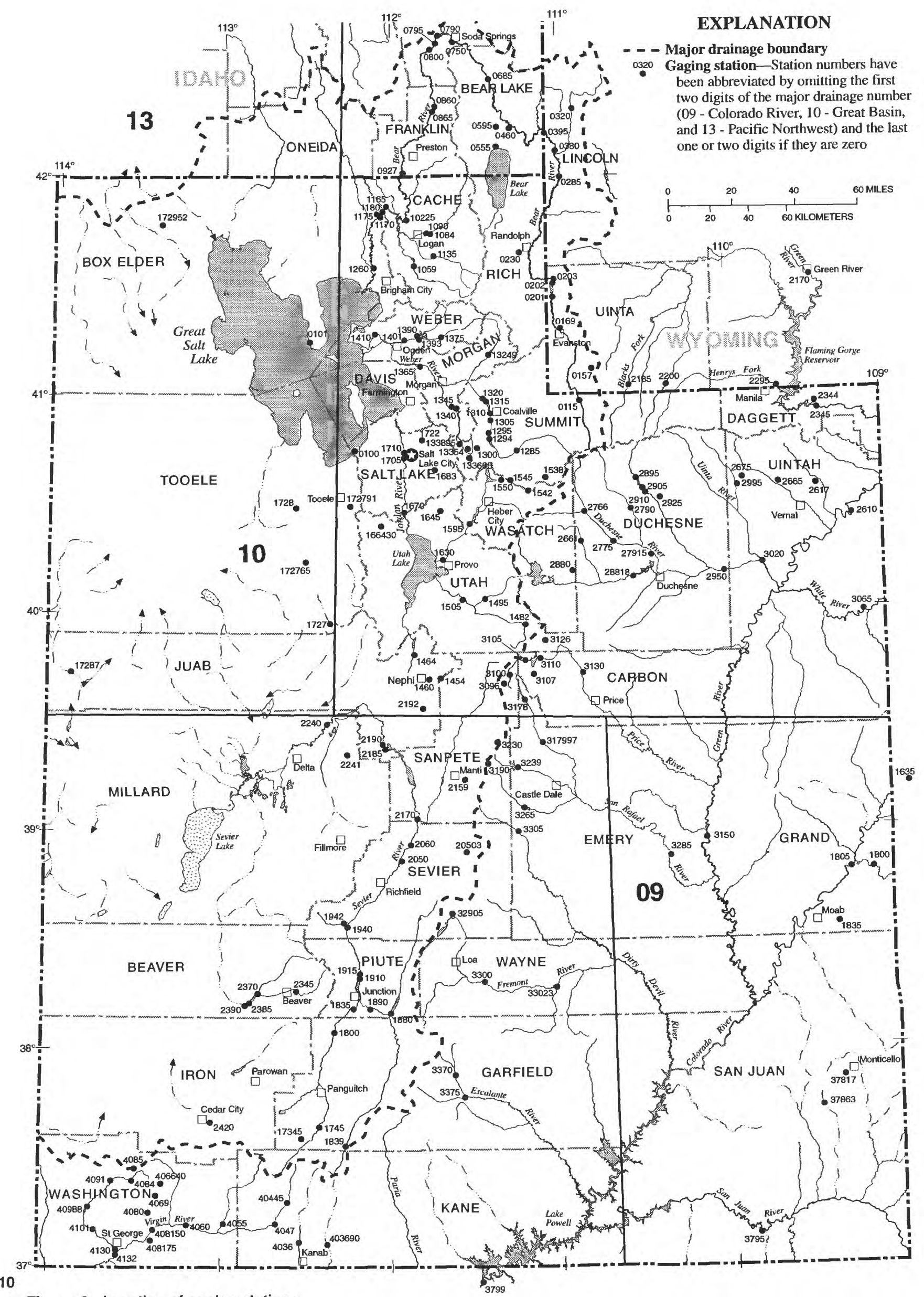

Figure 2. Location of gaging stations. 


\section{Ground-Water Data and Ground-Water Conditions in Utah}

\section{Project Number: UT-00-002}

Cooperating Agencies: Utah Division of Water Rights; Utah Division of Water Resources; Central Utah Water Conservancy District

Staff: $\quad$ L.R. Herbert, Hydrologic Technician, Project Chief (part time)

Other District personnel as assigned

\section{Period of Project: Continuing}

Problem: Long-term records of water levels and ground-water withdrawals are needed to evaluate the effects of climatic variations, to determine the effects of withdrawals from aquifers on water levels, to assist in the prediction of future conditions of aquifers, and to provide data for management of ground-water resources.

Objectives: (1) To obtain long-term records of ground-water levels for determination of water-level changes for yearly or other periods, (2) to determine withdrawals from aquifers in the State, and (3) to make an annual evaluation of ground-water conditions in Utah and publish the information in a report.

Approach: Measure water levels annually (normally during February and March) and operate continuous waterlevel recorders on selected observation wells (fig. 3). Measure discharge or obtain amounts of discharge from irrigation wells in 17 selected valleys; determine the ratio of water produced to energy consumed, and use the ratio along with energy-consumption data to help compute total annual withdrawal from wells for irrigation. Measure discharge from selected flowing wells. Obtain estimates of ground water withdrawn from wells for public supply and industrial use from the Utah Division of Water Rights. Obtain additional estimates of industrial or public-supply use of water from wells by interviewing users. Determine the number and diameter of new wells drilled annually from well drillers' reports filed with the Utah Division of Water Rights. Prepare an annual report on ground-water conditions in Utah that includes data, graphs, and maps showing water-level changes; withdrawals from wells; number of wells drilled in defined ground-water basins or areas; changes in ground-water quality; and a discussion of ground-water conditions in each basin or area with substantial withdrawals. Store water-level data in computer files and publish selected data in the annual report of water-resources data for Utah.

Progress: Water levels were measured in about 1,000 wells in February and March. In addition, water levels in 2 of these wells were measured monthly, and continuous water-level recorders were maintained on 27 of these wells. During the irrigation season, about 500 discharging irrigation wells were observed; discharge was measured at about one-half of the wells, and the ratio of water production to energy consumption was determined. Natural flow was measured for about 30 wells during the irrigation season. Number and diameter of wells drilled during the past year were compiled. The thirty-first in the series of annual reports on ground-water conditions in Utah was completed. The continuous water-level records were published in the Water resources data for Utah, water year 1993 report.

Plans for Next Year: Continue collecting, recording, and publishing data on water levels, ground-water withdrawals, and wells drilled. The thirty-second in the series of annual ground-water reports will be compiled.

Reports:

Allen, D.V., Garrett, R.B., and others, 1994, Ground-water conditions in Utah, spring of 1994: Utah Division of Water Resources Cooperative Investigations Report 34.

ReMillard, M.D., and others, 1994, Water resources data for Utah, water year 1993: U.S. Geological Survey WaterData Report UT-93-1. 


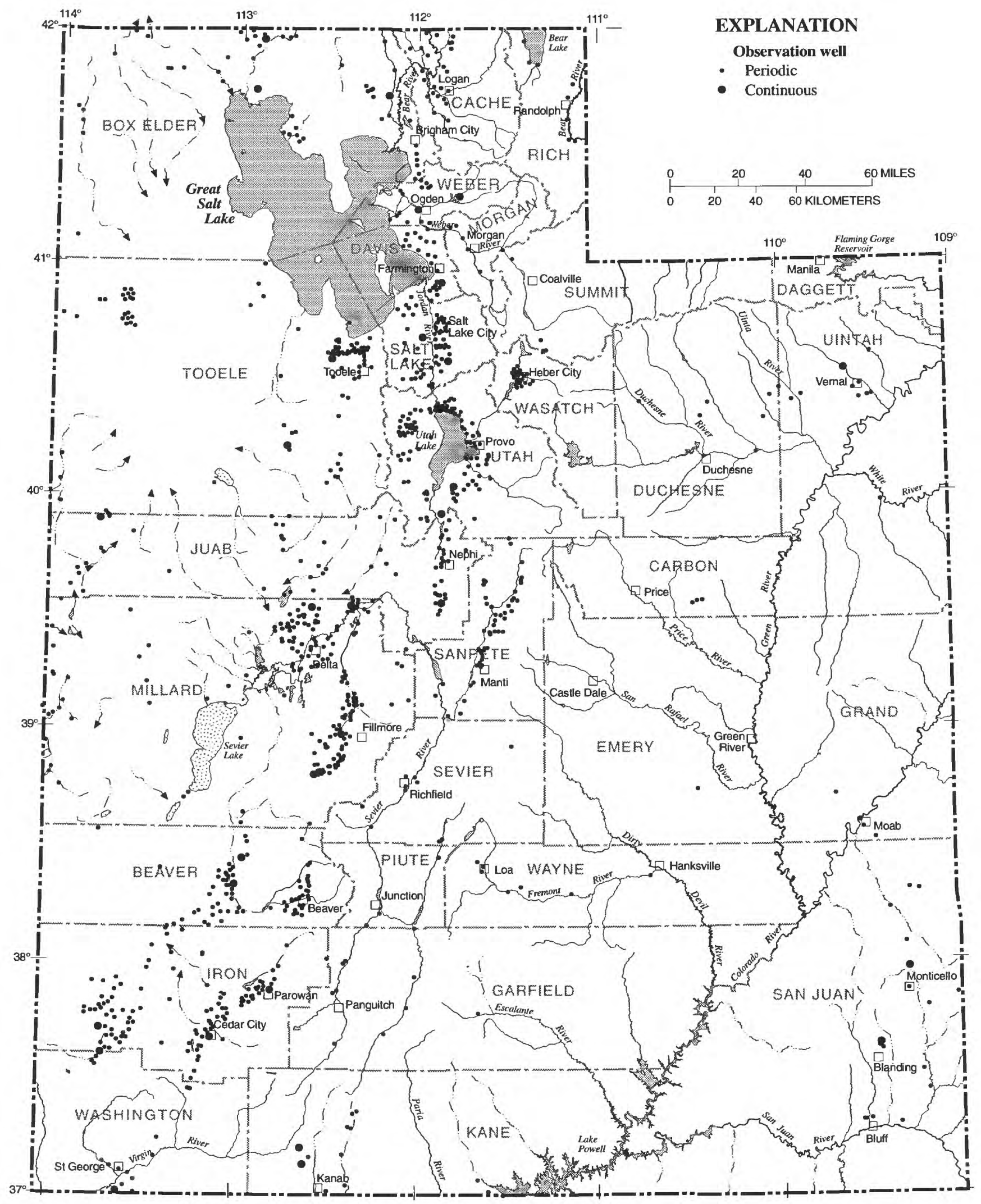

Figure 3. Location of observation wells in which water levels were measured. 


\section{Project Numbers: UT-00-003; UT-00-004; UT-00-005}

Cooperating Agencies: Utah Division of Water Resources; Utah Division of Water Rights; Utah Division of Oil, Gas, and Mining; Bureau of Reclamation; Central Utah Water Conservancy District

Staff: $\quad$ L.R. Herbert, Hydrologic Technician, Project Chief (part time)

Other District personnel as assigned

Period of Project: Continuing

Problem: Data on the quality of surface and ground water and the amounts of sediment loads in selected rivers are needed for surveillance, planning, design, and management of water-resources activities. Water-quality problems can affect industries, water-treatment facilities, irrigators, and individuals. Sediment reduces storage in reservoirs, contaminates water supplies, and harms fisheries. Sediment and precipitation data are needed for erosion studies, reservoir design, evaluation of water quality, and water-resources management. Data bases are needed to provide the appropriate water-quality, sediment, and precipitation information.

Objectives: To obtain records of quality of water from streams and wells, sediment, and precipitation at selected sites throughout Utah.

Approach: Use standard methods for the collection and analysis of precipitation data; chemical-quality, fluvial-sediment, and biological samples, and computer storage and publication of data.

Progress: Water samples for chemical analysis were obtained periodically at 15 stream sites (fig. 4) using the parts per billion inorganic sampling protocol. In addition, continuous or daily temperature and/or specific-conductance data were obtained at eight of these stream sites. Water from about 20 surface-water sites in Utah, Uinta, and Duchesne Counties was sampled using the parts per billion inorganic sampling protocol. About 200 wells are in the ground-water-quality monitoring program (fig. 5), and complete chemical analysis was obtained for water from about 70 wells. Water from 10 wells was sampled in an area of oil-field brine injection in the Uinta Basin. All water-quality data for streams and wells are listed in the annual water-resources data reports. Sediment data were obtained continuously at two sites and periodically at an additional eight sites.

Plans for Next Year: Continue collecting water-quality data from selected surface-water sites using the inorganic sampling protocol. Continue processing data and preparing records for publication. Continue collecting waterquality data from the State ground-water network and from selected wells in the brine-injection area of the Uinta Basin. Continue collecting and processing sediment data and preparing records for publication. Continue collecting precipitation data.

Reports:

ReMillard, M.D., and others, 1994, Water resources data for Utah, water year 1993: U.S. Geological Survey WaterData Report UT-93-1. 


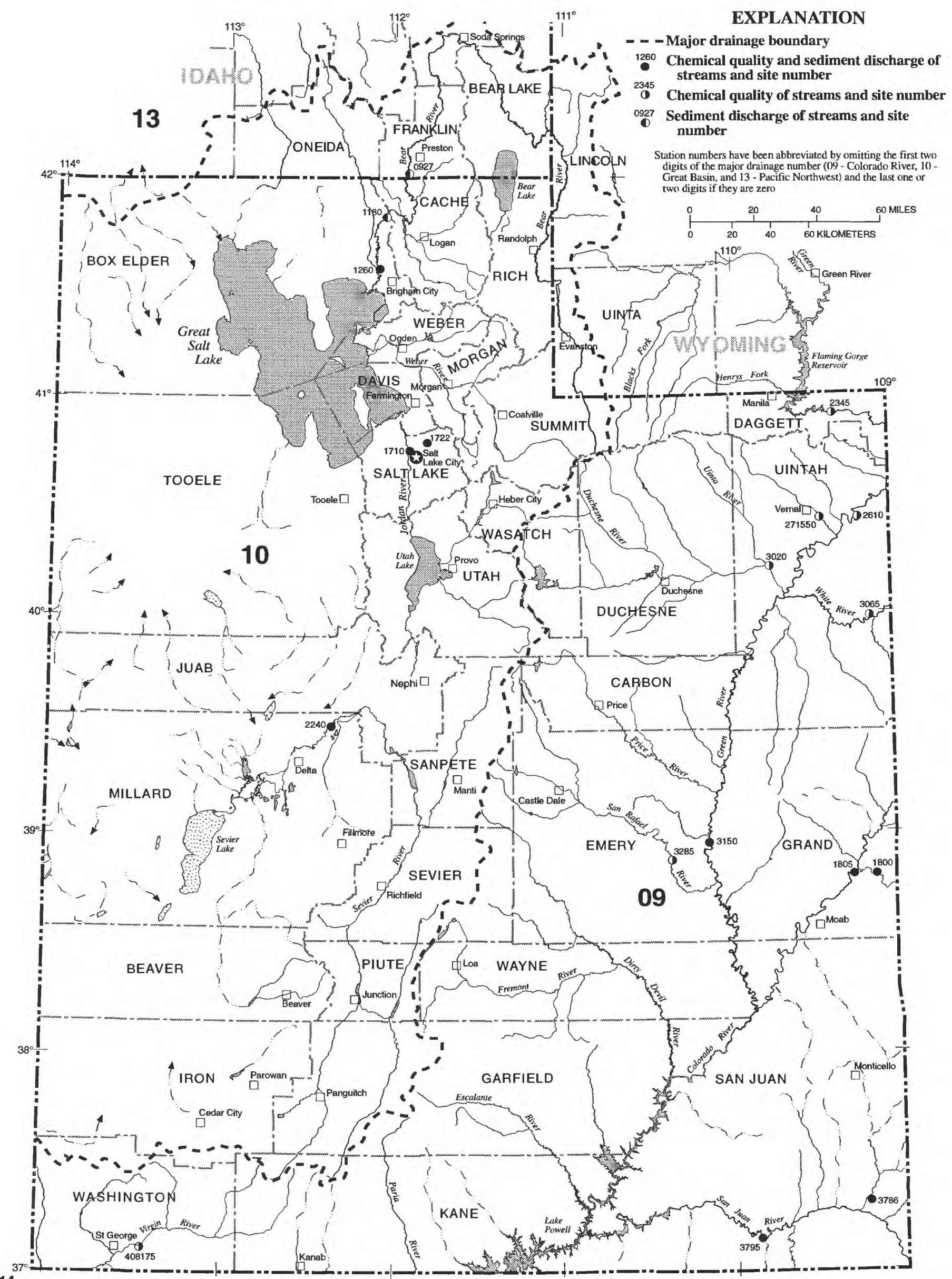

Figure 4. Location of surface-water-quality stations. 


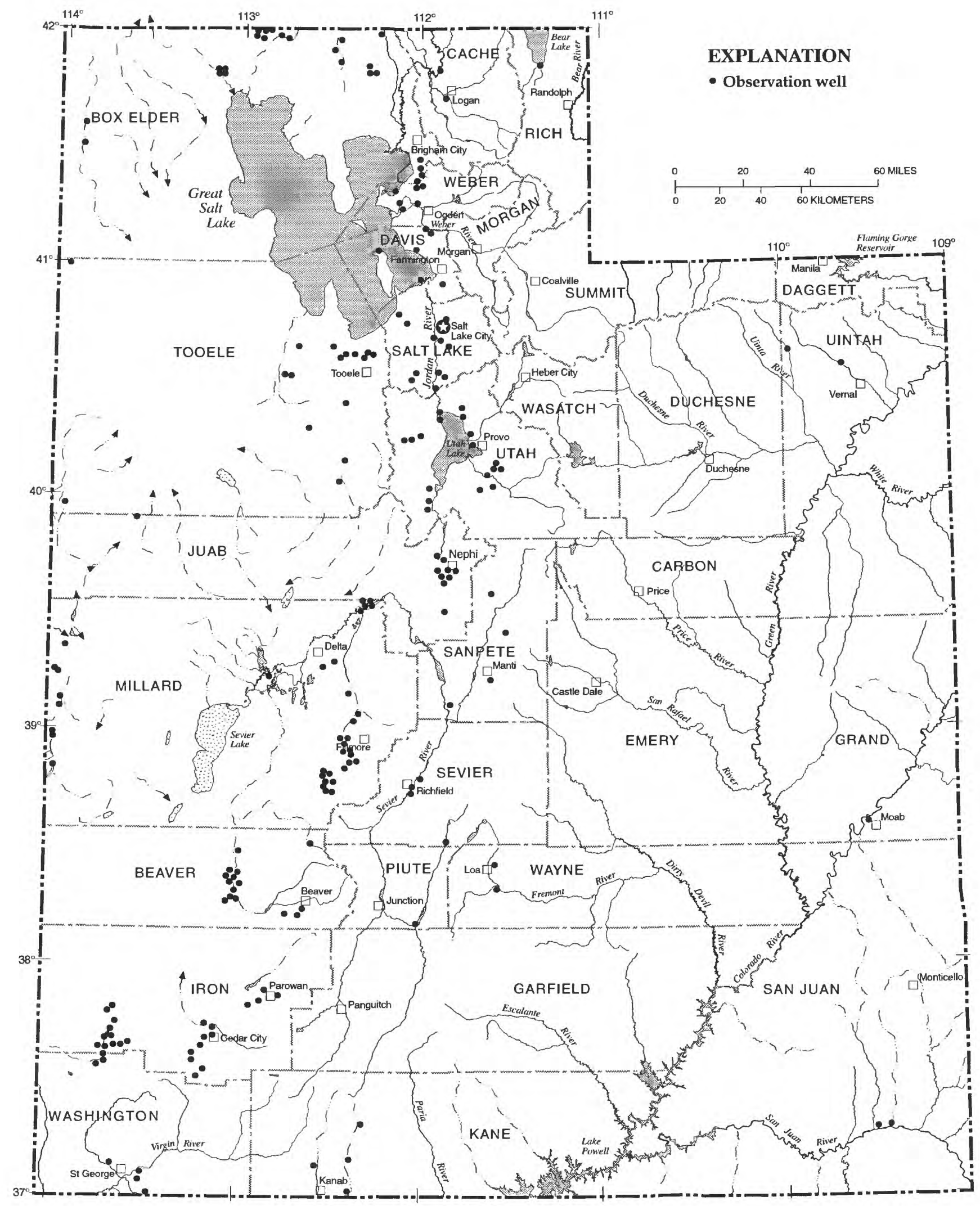

Figure 5. Location of observation wells where water samples were collected for monitoring water quality. 
Interpretive Studies

Locations of interpretive studies discussed in this section are shown in figure 6.

\section{Statewide Water Use}

\section{Project Number: UT-00-007}

Cooperating Agencies: Utah Division of Water Rights; Utah Division of Water Resources

Staff: $\quad$ H.K. Hadley, Hydrologist, Project Chief (part time)

K.K. Wilson, Hydrologic Technician (part time)

Period of Project: Began July 1977, continuing

Problem: In 1977, the U.S. Congress recognized the need for consistent, current, and reliable information on water use for the entire United States and directed the U.S. Geological Survey to set up a program to collect, compile, and publish such data. These data are needed to document trends in water use to aid in the management of the Nation's water resources.

Objectives: To obtain information about withdrawals, return flow, and consumptive use of water in connection with each type of withdrawal.

Approach: Determine total water diversions and consumptive use by verification of user measurements and records and, where possible, by field inventory and measurement of surface-water diversions and selected types of ground-water diversions. Use acreage and crop surveys to aid in estimating consumptive use by irrigation. State personnel are collecting data on public-supply and industrial use; U.S. Geological Survey personnel are collecting data on irrigation use.

Progress: Mail surveys were done by the Utah Division of Water Rights to determine water use by about 390 public water suppliers and about 120 major self-supplied and public-supply industries. Funding was obtained to begin a municipal consumptive water-use project in St. George, Utah, an arid area with a rapidly growing population.

Plans For Next Year: A State water-use report containing 1985 to 1990 data will be sent out for review. Flowmeter data will be collected for the municipal consumptive water-use project in St. George. A paper on the St. George study will be presented at the American Water Resources Association meeting in Salt Lake City. 


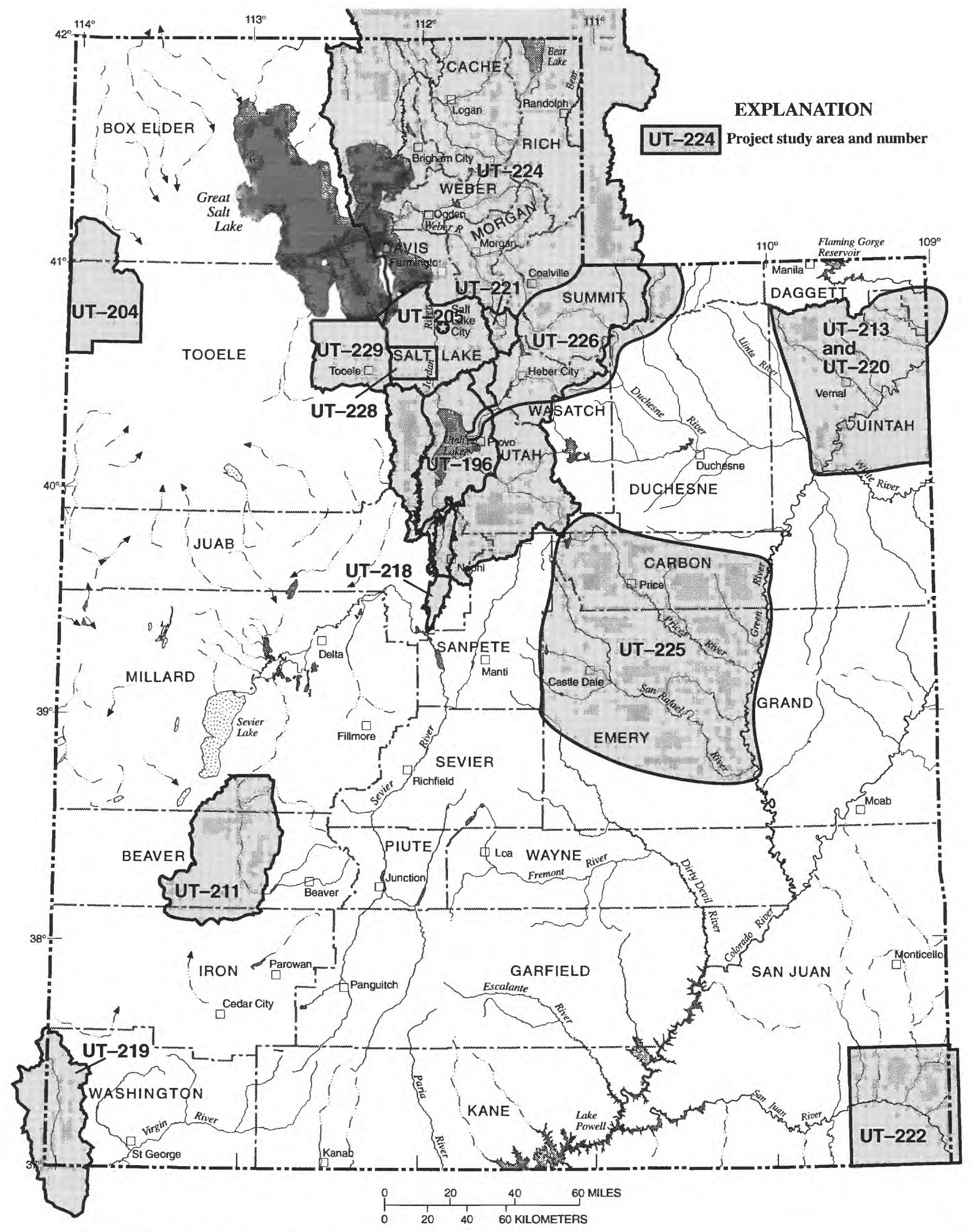

Figure 6. Location of interpretive studies. 


\section{Ground Water in Southern Utah and Goshen Valleys, Utah County, Utah}

Project Number: UT-88-196

Cooperating Agency: Utah Division of Water Rights

Staff: $\quad$ L.E. Brooks, Hydrologist, Project Chief (part time)

B.J. Stolp, Hydrologist

Period of Project: October 1988 to September 1994

Problem: Southern Utah and Goshen Valleys are along the Wasatch Front, where most of Utah's populatic $\eta$ is located and where population growth is rapid. Thick basin-fill deposits contain large volumes of good-qualit.' water that has been developed for irrigation, municipal, and industrial use. Further development of ground water, most of which is proposed for municipal use, has been limited because of the probable effects on surface water that drains to Utah Lake and the effects on the lake itself, which is a source of water for irrigation downstream. In addition, many wells flow under artesian pressure, and additional ground-water development likely would cause some wells to stop flowing. The State would like to know the effects that additional ground-water development would l qve on water levels, surface water, and water quality, and the effects of importing additional surface water, by the Central Utah project, on the ground-water system.

Objectives: (1) To assess current hydrologic conditions in terms of recharge, movement, and discharge of ground water, water levels, ground-water quality, and volumes of ground water in storage; (2) to better define the groundwater system and how its components interact; and (3) to estimate the effects of additional ground-water withdrawals on water levels and water quality and the effects of importation of additional surface water on the ground-water system.

Approach: (1) Compile existing data on wells, springs, water levels, ground-water quality, and surface-water flow; (2) inventory or estimate ground-water discharge from wells and springs, to drains and streams, and by evapotranspiration and seepage to Utah Lake; (3) estimate recharge, where feasible, from streams, irrigation, precipitation, and subsurface flow from consolidated rock; (4) conduct aquifer tests to improve knowledge of hydraulic characteristics of the basin fill; (5) construct a three-dimensional digital model of the ground-water system to simulate and better understand ground-water flow, and estimate effects of proposed changes in water use on the system; and (6) prepare a basic-data report and an interpretive report for publication by the Utah Department of Natural Resources.

Progress: Addressed review comments on the interpretive report.

Plans for Next Year: Complete review and publish the interpretive report. Archive the computer ground-water flow model and geographic-information-system data.

\section{Reports:}

Stolp, B.J., Drumiler, Marilyn, and Brooks, L.E., 1993, Selected hydrologic data for southern Utah and Goshen Valleys, Utah, 1890-1992: Utah Hydrologic-Data Report No. 50. 
Identification and Quantification of Mechanisms Causing Decreasing

\section{Salt-Crust Thickness, Bonneville Salt Flats, Western Utah}

Project Number: UT-90-204

\section{Cooperating Agency: Bureau of Land Management}

Staff: J.L. Mason, Hydrologist, Project Chief

W.C. Brothers, Hydrologist (part time)

G.E. Pyper, Hydrologist (part time)

P.S. Muir, Hydrologic Technician

K.L. Kipp, Hydrologist, National Research Program, Denver, Colorado (part time)

Period of Project: January 1990 to September 1994

Problem: From 1960 to 1988, a decrease of the salt-crust thickness at the Bonneville Salt Flats equated to a decrease in volume of 34 million cubic yards ( 40 million tons). The decrease is of concern to the Bureau of Lant Management because the Bonneville Salt Flats are a unique geologic feature and recreation area, and according to management plans drafted in 1985, should be preserved for future generations.

Objectives: (1) To document changes in the hydrologic system of the Bonneville Salt Flats since the Utah District's study by Lines (1979); (2) to establish a data-collection network to monitor changes in water levels, water chemistry, and salt thickness at the Bonneville Salt Flats; (3) to assess the potential for removal of salts from the salt-flats area through wind-driven ponds; and (4) to assess the effects of current brine withdrawals, other human-induced variations, and climatic changes on the hydrologic system.

Approach: (1) Prepare a detailed plan of study and review entire plan with the Bureau of Land Management (BLM) and the Technical Review committee formed by BLM. (2) Define formation and movement of ponds using LAANDSAT data and available aerial photography of the salt-flats area. (3) Develop a three-dimensional solute-transport model. (4) Compile data collected or available since the Lines (1979) study, including brine-withdrawal, water-level, chemical-analysis, meteorological, soil-moisture, and other pertinent data for the past 12 years. (5) Locate observation wells drilled during and prior to the Lines study (1979). (6) Establish an observation-well network to measure water levels monthly and collect samples of brine for density analysis. (7) Drill new observation wells on and adjacent to the salt flats. Cores will be collected and analyzed for mineralogical content. Salt thickness and water levels will be measured, samples of brine will be collected and analyzed, and the wells will be added to the observationwell network. Nested wells (adjacent wells completed at different depths) will be part of the drilling plan to determine vertical variation in water levels, water density, and chemistry. One or more production wells ( 8 inches or larger) and several observation wells near each production well will be drilled for use in an aquifer test or tests. (8) Conduct and analyze aquifer tests. (9) Conduct geochemical studies to estimate geochemical flow paths and reactions along these paths and to describe processes that may increase or decrease salt thickness and areal extent. (10) Prepare reports documenting the results of the study.

Progress: Water levels were measured in observation wells during October 1993 at the same time that the final altitude and location field survey was completed by the BLM. The altitude and location data were used to cor"ect for density variation in all water-level measurements. The density-corrected data for each measurement periof were plotted and contoured for the Bonneville Salt Flats and Pilot Valley. The water-level contours are similar to those shown in a previous study and indicate that the shallow brine underlying the Bonneville Salt Flats is in steady state with respect to a fluid balance. Three Thematic Mapper satellite images that include the Bonneville Salt Flats and Pilot Valley have been obtained for September 1992 and March and August 1993. These scenes were used in conjunction with measurements of the salt crust to estimate the volume of salt redistributed by the movement of surface ponds during the winter of 1992-93. A three-dimensional solute-transport model of the shallow-brine aquifer is being developed using the HST code, which has been modified to accommodate specific conditions on the Bonneville Salt Flats. Although the shallow-brine aquifer appears to be in steady state over a period of several years, it varies on a seasonal basis. Water levels decline in the summer months as a result of evaporation and brine withdrawal for mineral production. Water levels recover in the winter months as a result of increased infiltration and the lack of evaporation and brine withdrawal. Because no measurable steady-state water-level surface exists, a synthetic 
steady-state calibration was obtained to determine the required net recharge necessary to balance known sub rurface discharge from the shallow-brine aquifer. The calibrated net recharge will be used to balance evaporation in $\mathrm{tl}:$ summer months with recharge in the winter months in a cyclic seasonal or transient steady-state simulation over $\hat{c}$ period of several years. The transient steady-state simulation will use the same boundary conditions for each summer and winter season. The calculated solute transport at the end of the transient steady-state simulation will be independent of the initial conditions.

Plans for Next Year: Complete calibration of solute-transport model. Complete data report. Prepare draft of final interpretive report. 


\section{Ground-Water Flow and Solute Migration in Salt Lake Valley, Utah}

\section{Project Number: UT-90-205}

Cooperating Agencies: Utah Division of Water Rights; Utah Division of Water Quality; and local municipalities and water agencies

Staff: $\quad$ G.W. Freethey, Hydrologist, Project Chief (part time)

S.A. Thiros, Hydrologist

P.M. Lambert, Hydrologist

V.M. Heilweil, Hydrologist (part time)

Period of Project: March 1990 through September 1994

Problem: The Utah Divisions of Water Rights and Water Quality are facing a dilemma as ground-water resources are developed in Salt Lake Valley. Currently allocated water rights are thought to exceed the total annual inflow of good-quality ground water to basin-fill material in the valley. The Division of Water Rights needs to know the effects of additional ground-water development on the hydrologic system. Both Divisions need to determine the source area for water withdrawn from proposed wells at several locations within the valley to anticipate and prevent migration of poor-quality water to points of withdrawal, and thus to better manage development of the principal aquifer.

Objectives: (1) To better define the quality of water in the shallow unconfined aquifer of the Salt Lake Valley ground-water system and underlying confining units; (2) to determine the hydrologic properties of the shallow unconfined aquifer and underlying confining units; (3) to better define the ground-water/hydrochemical flow system, including three-dimensional variation of hydrologic properties and ground-water quality in the principal aquifer and in the shallow unconfined aquifer and confining units; and (4) to determine the effect of increased withdrawals from public-supply wells on water quality.

Approach: The approach to achieving the objectives involves several components of field investigation and information interpretation. These components are integrated, and each is necessary to accomplish the stated objectives. In general, these components are to (1) determine properties of the shallow unconfined and principal aquifers and the confining unit and the chemical composition of the water by drilling, field testing of water-level response to withdrawals from wells, and laboratory testing of cores and water samples; (2) determine the extent of the effects of variable-density fluid on fluid movement; (3) update and refine the existing ground-water flow model; (4) conduct particle-tracking and solute-transport simulations using the model to increase knowledge about the sou"ce and movement of water with high concentrations of dissolved solids; and (5) synthesize collected information and prepare reports.

Progress: The interpretive report, titled "Chemical composition of ground water, hydrologic properties of besin-fill material, and ground-water movement in Salt Lake Valley, Utah," currently is in review.

The report titled "Numerical simulation of ground-water flow in basin-fill material in Salt Lake Valley, Utar." documenting the development and calibration of a three-dimensional ground-water flow model for Salt Lake Valley, has received editorial and colleague reviews and currently is awaiting a final editorial review before being sul 'mitted for approval.

The calibrated flow model was used to investigate the movement of ground water in the vicinity of selected pumping wells. The particle-tracking program MODPATH was linked with the ground-water flow model to defire flow paths and velocities within capture zones of selected sets of wells in the valley. Three sets of wells, currently discharging from zones of good-quality ground water but in close proximity to zones of poorer-quality or contarninated ground water, were selected for analysis. Capture zones of selected wells were based on simulation results of two ground-water use scenarios. The first simulation incorporated pumpage representing current average withdrawals as determined from 1992-93 reported values. In the second simulation, discharge from public-supply wells was increased from 1992-93 average rates to projected rates of withdrawal for the year 2025 as estimated by Utah State University, the Utah Division of Water Resources, and the Bureau of Reclamation during the development of a water-demand/water-supply model for the Wasatch Front. Twenty-five-year and 50-year capture zones for each well 
set were defined and compared with the distribution of dissolved solids in the ground-water system to determine the quality of ground water within the zones. The report documenting the particle-tracking analysis has had supervisory and initial editorial review and is being prepared for colleague review.

The three-dimensional solute-transport model MT3D has been linked to the calibrated flow model. Preliminary transport simulations using simplified sets of model parameter values have run successfully. The transport model uses output defining heads and cell-by-cell fluxes from the calibrated flow model and can simulate the advective and dispersive transport of a solute and the effects of source/sink mixing on solute concentrations. The final report documenting solute-transport simulations is in preparation.

Plans for Next Year: Reports will be prepared and published. 


\section{Recharge to Basin-Fill Aquifers from Irrigation, Southwestern Utah}

Project Number: UT-91-211

Cooperating Agency: Utah Division of Water Rights

Staff: $\quad$ D.D. Susong, Hydrologist, Project Chief

Other District personnel, as assigned

Period of Project: October 1991 to September 1994

Problem: Irrigators are converting from flood- to sprinkler-irrigation systems in some areas of Utah and are requesting to expand irrigated acreage based on water saved because of conversion. This change in irrigation methods probably will affect recharge to basin-fill aquifers, and these effects are largely unquantified. An understanding of how this change in irrigation methods might affect the quantity of ground-water recharge to the basin-fill axuifers is needed to better manage future ground-water withdrawals and to determine whether it is justified to permit expansion of irrigated acreage based on water savings using sprinkler systems.

Objective: Determine the quantity of recharge to basin-fill aquifers from flood-and sprinkler-irrigation methods.

Approach: Recharge to basin-fill aquifers will be determined by water-budget and infiltration-rate methods. A study site of paired flood- and sprinkler-irrigated fields in the Milford area will be instrumented with (1) monitoring wells and neutron-access tubes, (2) tensiometers, (3) weirs, (4) flow meters, and (5) automated weather stations. The VS2D unsaturated-flow model will be used to evaluate infiltration and downward flow at each site.

Progress: The water budgets for both the flood- and the sprinkler-irrigated field have been completed, and model calibration is complete. The report was completed, reviewed, and submitted for approval.

Plans for Next Year: Receive approval and publish report. 
Hydrologic Study of Lower Ashley Creek, Uintah County, and Monitoring for

Remedial Activities Related to Selenium Contaminants,

Middle Green River Basin, Utah

Project Number: UT-91-213

Cooperating Agencies: Bureau of Reclamation; U.S. Fish and Wildlife Service

Staff: D.W. Stephens, Hydrologist, Project Chief

Other District personnel, as assigned

Period of Project: October 1990 to September 1994

Problem: Studies completed at Stewart Lake Waterfowl Management Area (WMA), Ashley Creek, and Ouray National Wildlife Refuge (NWR) identified several areas where selenium was adversely affecting the beneficial use of water and creating a hazard to wildlife. The studies showed the source of contamination at Stewart Lake W'MA to be drainwater from soils derived from Mancos Shale. Median concentrations of selenium in drainwater discharged to Stewart Lake exceeded the State standard of 5 micrograms per liter $(\mu \mathrm{g} / \mathrm{L})$ established for wildlife protect in and were as high as $140 \mu \mathrm{g} / \mathrm{L}$. The lake was an effective sink for dissolved selenium and retained 75 percent of the total inflow load in sedimentary deposits. Selenium concentrations in waterfowl tissue at Stewart Lake WMA were high, ranging from 1.9 micrograms per gram $(\mu \mathrm{g} / \mathrm{g}$ ) (dry weight) in Canada goose muscle to $87 \mu \mathrm{g} / \mathrm{g}$ in American coots.

The studies showed that the source of contamination in Ashley Creek was inflow of shallow ground water and surface water that originates from a sewage-lagoon system and flows through Mancos Shale, mobilizing selenium. Selenium concentrations in ground water that seeps into Ashley Creek were as high as $16,000 \mu \mathrm{g} / \mathrm{L}$. Waterfowl contained selenium concentrations as high as $50.3 \mu \mathrm{g} / \mathrm{g}$ in liver and $27.2 \mu \mathrm{g} / \mathrm{g}$ in muscle tissue.

Selenium contamination of ponds at Ouray NWR was limited to a small area on the western part of the refuge, and the studies showed the contamination to be a result of seepage of shallow ground water into ponds used by waterfowl. The Bureau of Reclamation needs additional information on selenium contamination in the middle Green River basin and assistance in designing a monitoring system to evaluate any remedial activities they may undertake.

Objectives: Further define the hydrologic system for Ashley Creek and complete a selenium mass-balance model. Design and implement a monitoring program for selenium contamination for Stewart Lake WMA, Ouray NW'R, and the Green River that will provide data needed to evaluate possible remedial actions. Formulate and evaluate potential remedial actions.

Approach: (1) Sample water and sediment to determine the sources of selenium entering Ashley Creek and the Green River; (2) quantify the extent of sediment contamination in ponds at Ouray NWR and in Stewart Lake; (3) design a monitoring program to assess changes in the aquatic systems with time and in response to remedial action in the middle Green River basin; (4) obtain public input on potential remedial options; and (5) assemble and evaluate options to select the preferred package for remediation.

Progress: Data collection continued for selenium monitoring at Stewart Lake and on the Green River. Total loading of selenium to the Green River is about 2.2 pounds per day from Stewart Lake but is greater than 6 pounds from Ashley Creek. More than 80 options for selenium remediation at Stewart Lake were condensed to 7 alternative packages after evaluation of public comment and technical evaluation. Preliminary cost estimates for the alternatives range from 3 million to about 30 million dollars. Costs for remediation of selenium contamination of Ashley Creek through abatement of leakage of waste-water lagoons are estimated to be almost 8 million dollars but are not currently being considered for action under U.S. Department of the Interior programs.

Plans for Next Year: Determine if storm loading of selenium to the Green River is high enough to prevent use of diluted drainwater from Stewart Lake during critical periods for Razorback Sucker reproduction. Install instrıments for continuous monitoring of drainwater flow into Stewart Lake. Continue public meetings and evaluation $c^{f}$ alternatives. Complete draft Environmental Impact Statement and planning report (primarily by Bureau of Reclamation) for the alternative package. 


\section{Ground Water in Juab Valley, Juab County, Utah}

Project Number: UT-92-218

Cooperating Agency: Central Utah Water Conservancy District; East Juab County Water Conservancy District

Staff: $\quad$ S.A. Thiros, Hydrologist, Project Chief (full time)

J.I. Steiger, Hydrologist (part time)

H.K. Hadley, Hydrologist (part time)

B.J. Stolp, Hydrologist (part time)

Period of Project: January 1992 to September 1995

Problem: Water will be imported into Juab Valley, mostly for irrigation, as part of the Central Utah Project. The Central Utah Water Conservancy District wants to optimize the size of the pipeline delivering water to Juab Valley and needs to know how much of local peak demand can be met by ground water. The East Juab County Water Conservancy District wants to optimize use of water in the valley, including local surface water, local ground water, and imported water, and needs information on ground water and the effects of its development in order to irtegrate ground-water use and development into the overall water-management plan for Juab Valley.

Objectives: (1) To assess current ground-water conditions and document changes since previous studies during 1962-66; (2) to define and quantify the ground-water system of the valley-hydrologic properties, estimated recharge, movement, estimated discharge, and water quality; (3) to evaluate current and potential sources of groundwater salinity in the southern end of the valley; and (4) to provide a tool to understand the valley's ground-water system and to estimate the effects of changes in ground-water withdrawals or recharge on water levels, natural discharge, and water quality.

Approach: (1) Compile all available data and inventory significant new wells and selected springs; (2) measure water levels in wells and prepare a potentiometric-surface map; (3) use drillers' logs to improve definition of basinfill deposits; (4) conduct aquifer tests to improve definition of hydrologic properties; (5) estimate and measure the components of recharge and discharge; (6) analyze water samples to better define water-quality problems; and (7) construct and calibrate a three-dimensional model of ground-water flow.

Progress: A multi-well aquifer test was done in the Levan area in October 1993. A gain-loss study was done on Salt Creek through Nephi and on its south diversion in November 1993. A reconnaissance of West Creek was done in December 1993. Analysis of the data collected has been completed.

Average annual streamflow from drainages entering the east side of Juab Valley was estimated. The distribution of irrigated land and wetland areas in the valley and associated irrigation methods was converted to geographic-information-system coverage. The ground-water budget components were estimated and water-quality data were analyzed. The ground-water flow model for Juab Valley has been constructed and is being calibrated. The data report is in the review process and the interpretive report is being written.

Plans for Next Year: Publish the data report. Complete the ground-water flow model and the interpretive report. 


\section{Hydrologic Reconnaissance of the Beaver Dam Wash Area of the Virgin River Basin, Washington County, Utah, Mohave County, Arizona, and Lincoln County, Nevada}

Project Number: UT-92-219

Cooperating Agencies: Utah Division of Water Resources; Nevada Department of Conservation and Natural Resources, Division of Water Resources; Arizona Department of Water Resources; and Bureau of Land Management

Staff: G.E. Pyper, Hydrologist, Project Chief (retired volunteer)

W.F. Holmes, Supervisory Hydrologist (part time)

M. Enright, Lead Hydrologic Technician (part time)

Period of Project: December 1992 to September 1995

Problem: The area that includes southwestern Utah, southeastern Nevada, and the northwestern corner of Arizona is one of the fastest-growing areas in the western United States. The three States would like to know the extent of water resources in the Beaver Dam Wash drainage basin, an undeveloped basin that includes parts of all three States and in which little is known about surface and ground-water resources. The States also would like to know the potential effects of developing water in the riparian areas of the basin.

Objectives: (1) Improve understanding of surface water and surface-water quality, including estimating average annual flow at selected locations and mapping perennial reaches; (2) improve understanding of ground water by defining aquifers; estimating recharge, discharge, direction of movement, aquifer properties, and storage; and defining water quality; (3) define the relation between surface and ground water; and (4) estimate a water budget for Beaver Dam Wash and determine annual surface- and ground-water flow from Beaver Dam Wash to the Virgin River.

Approach: (1) Compile available surface-water data, correlate data from the new streamflow-gaging station in Beaver Dam Wash with nearby long-term stations to estimate long-term flow at the site, install a stream gage at the mouth of the wash, install a crest-stage gage at Lytle Ranch, use channel geometry to estimate average flow at selected locations on major tributaries, map perennial reaches of streams from the air, and sample surface w`ter for chemical analysis; (2) compile available ground-water data; inventory and sample wells and springs; construct potentiometric-surface maps; conduct geophysical surveys to define basin-fill thickness and character; drill, $\log$, and sample test-holes at one or more sites and conduct simple aquifer tests; conduct an aquifer test in the lower part of the basin where producing wells exist; use collected data to estimate quantity of ground water in storage; and conduct a reconnaissance survey of the outcrops of Navajo Sandstone in the upper part of the wash to estimate groundwater conditions; (3) conduct seepage runs, at low flows, of major perennial reaches; and use available aerial reconnaissance, seepage, and ground-water data to classify reaches as seasonally or perennially gaining or losing; and (4) estimate surface-water outflow to the Virgin River; estimate ground-water outflow to the Virgin River valley; and estimate a water budget for Beaver Dam Wash.

Progress: During October 1993 through September 1994, earth-resistivity and seismic-refraction surveys of the unconsolidated basin-fill deposits along four roughly east-west traverses and one roughly north-south traverce, were completed. A preliminary report from the Geologic Division on this activity was reviewed and returned. Four test wells, one in Arizona and three in Utah, were drilled, completed, and logged. Slug tests were run on two of the test wells. A comprehensive aquifer test of the channel fill at the mouth of Beaver Dam Wash was completed; in addition, a single well test was run for 8 hours on a large well. Water-level measurements of 67 wells during February 1994 were made. Water samples at four springs were collected. A late-year seepage run of surface water in October 1993 was completed. Tables of selected wells, drillers' logs, geologic logs, and discharge measurements were completed. Plots of geologic cross sections were done. Two project reviews were held with the cooperators.

Plans for Next Year: From October 1994 through September 1995, plans are to (1) remove recording equipment from well and stream locations; (2) complete data analyses; (3) complete estimate of average ground-water flow to the Virgin River valley; (4) complete estimate of the volume of recoverable ground water in storage in the drainage and in each State's part of the area, if feasible; (5) complete estimate of water budget for the wash; (6) complete writing draft report and submit to the three cooperators for review comments; and (7) address review comments and submit report for approval. 


\section{Data Synthesis of Results of Investigations Conducted Under the}

\section{Department of the Interior National Irrigation Water-Quality Program}

Project Number: UT-93-220

Cooperating Agency: U.S. Department of the Interior National Irrigation Water-Quality Program

Staff: D.L. Naftz, Hydrologist, Project Chief

Period of Project: October 1992 through September 1995

Problem: Extensive geochemical and hydrologic data from 25 sites in the western United States have been collected during geochemical studies conducted under the Department of Interior's National Irrigation Water-Ouality Program. The multivariate data set provides an opportunity to identify the geochemical and hydrologic characteristics of landscapes in which trace elements have been identified in irrigation runoff. Because of the large geographic coverage of this data base, these characteristics can be used to determine where irrigation-induced water-quality problems may occur in other parts of the United States and in other countries.

Objectives: The overall objective is to identify geochemical commonalities and differences that affect water quality in irrigated areas in the western United States. Specific objectives of the project are to (1) use the constructed data base to identify how the hydrologic and geologic setting and geochemical, biologic, and human-induc:d processes affect the magnitude, seasonality, and extent of contamination problems; (2) develop the capability to determine where irrigation drainage water-quality problems might occur so that problem areas can be identified; and (3) identify weaknesses in the data and offer suggestions to future investigators to improve data collection.

Approach: Normative salt assemblages, ionic ratios, and stable isotopes will be studied separately and together to evaluate commonalities and differences in trace-element source areas and geochemical weathering cycles among the 25 study sites. Although marine shales are common trace-elements sources, little is known about trace-element source minerals or their weathering cycles, which mobilize the trace elements. The geochemical computer program SNORM will be used to calculate salt norms from the chemical analyses of water samples. The results from the SNORM calculations will be coupled with pattern-recognition modeling techniques to identify important trace-element weathering reactions. Results of the pattern-recognition modeling will be used to construct a geochemically based classification model using soft independent modeling by class analogy algorithms. This classificatior model will then be used to evaluate the potential for trace-element production in other areas without corresponding traceelement water-quality data applied to other areas.

Progress: Interpretation of simple-salt distributions was completed and results were described in a journal article currently in technical review. Research results were presented at the American Water Resources Association Summer Symposium (June 1994). A symposium paper on study results was published in the conference proceedings. An abstract on recent study results was prepared for presentation at the 1995 American Water Resources Asscriation Summer Symposium. The simple-salt classification model was applied to large geographic areas in Utah and Wyoming, and preliminary selenium classification maps were prepared. Preliminary work was completed to place the data base on the World Wide Web.

Plans for Next Year: Publish a journal article on classification modeling of simple-salt data. Use the HTML programing language to place selected parts of the data base on the World Wide Web for access over the Internet. Complete selenium classification maps for Utah and Wyoming by using the previously developed classification model and publish results in a technical journal. Present findings at the 1995 American Water Resources Association Symposium. Contribute to summary report. 
Water Resources of Snyderville Basin, Park City, and

Surrounding Communities, Summit County, Utah

Project Number: UT-93-221

Cooperating Agency: Utah Division of Water Rights

Staff: L.E. Brooks, Hydrologist (part time)

Paul Downhour, Hydrologic Technician (part time)

Period of Project: July 1993 to September 1997

Problem: For this study, the Park City area is defined as the southwestern corner of Summit County, including the valley area generally south of and straddling Interstate 80 through which East Canyon Creek flows (Snyderville Basin); the area around Park City, including Prospector Square and Deer Valley; and the area from Richardsor Flat to Tollgate Canyon. Population in this area has substantially increased from 1980 through 1993, and much of this increase has occurred since 1987. Housing, industrial, and commercial development in the area continues to increase, and ski areas plan to increase snow-making operations.

These activities are placing increasing demands on the ground- and surface-water resources in the area. One of the major constraints on development of additional residential areas and commercial activities is water supply. Surface water in the area is part of the Weber River drainage basin and is considered to be fully appropriated. Tl ore are concerns about the effect of increased withdrawals of ground water on springs, surface-water flow, and water levels in existing wells.

The quality of water in the Park City area is suitable for domestic purposes but could deteriorate with developing industry or if centralized sewage treatment cannot accommodate the increase in housing developments. At least two public-water suppliers have indicated that sulfate concentrations are increasing in water being pumped. The reason concentrations of certain dissolved constituents are increasing is not known but could be related to changes that have occurred in the hydrologic system as a result of development.

Objectives: The purpose of the study is to provide water-resources planners and managers with quantitative information on water resources in the Snyderville Basin-Park City area. Specific objectives of the study are to (1) define and describe the lateral and vertical extent of the principal aquifers in the area; (2) describe the hydrologic system, including hydrologic properties of the aquifer, surface-water discharge and variability, ground-water recharge, rate and direction of movement, discharge, and storage and water use; (3) improve existing water budgets of the area to give managers a more accurate tool to use for planning additional development; (4) define and describe the interaction of surface and ground water; (5) describe the chemical quality of the surface and ground water, and identify potential causes of increasing dissolved-solids concentrations; and (6) describe the hydrologic and hydrocl amical effects that could be expected to occur as development creates a steadily increasing need for more water.

Approach: (1) Collect hydrologic and geologic data that can be used to define the geometry of the principal aquifers; (2) formulate a concept of the hydrologic system and recharge and discharge using aquifer tests, fracture analysis, precipitation records, water-level data, water-use data, spring and streamflow measurements, and water-quality data; (3) define the chemical quality of surface and ground water and identify potential causes of increasing dissolved-solids concentrations; (4) if possible, develop tools to examine the water-balance relations in the project area; (5) prepare a report describing the analysis of the data and results of the study; and (6) prepare a report documenting the data collected.

Progress: Inventoried municipal wells and springs and created geographic-information-system coverages of geology and hydrologic-data sites. Conducted seepage investigation in Snyderville Basin. Held public meeting and two project reviews. Obtained well construction and aquifer-test data from local drillers and consultants. Established water-level monitoring network and made periodic measurements. Installed two stream gages, made measurements, and began work on ratings and diagrams. Data base was updated after well inventory.

Plans for Next Year: Continue collection of new and existing data on ground water, surface water, water quality, water use, and climate. Help local agencies with planned aquifer testing. 


\section{Using Multivariate Statistics and Pattern-Recognition Techniques to Define Possible \\ Migration Pathways of Saline Water into Fresh Ground Water, Aneth Area, Utah}

Project Number: UT-93-222

Cooperating Agencies: Utah Division of Oil, Gas, and Mining; Bureau of Land Management; Bureau of Reclamation; U.S. Environmental Protection Agency

Staff: $\quad$ D.L. Naftz, Hydrologist, Project Chief

L.E. Spangler, Hydrologist (part time)

Period of Project: October 1991 to September 1995

Problem: Many wells that penetrate the Navajo aquifer in the area of the Greater Aneth Oil Field yield water that is slightly to very saline, which is anomalous for this aquifer in southern and southeastern Utah. During the last 25 years, salinity levels have increased in several water wells completed in the Navajo aquifer. The most sutstantial increase is near the town of Aneth. This increase may have resulted from the injection of oil-production water rather than upward migration of brines from underlying salts. Because neither the extent nor the severity of the prcblem is known with any accuracy, an understanding of the regional hydrology and geochemistry of the Navajo acrifer is necessary to better evaluate the extent of contamination and the remedial measures that are required to alleviate continued migration of the saline brines.

Objectives: (1) To identify conservative and nonconservative inorganic, isotopic, and organic geochemical constituents that can be used to define the source(s) and path(s) of the saline water in the freshwater aquifers, and (2) to use the geochemical data from objective 1 in forward and inverse mixing models (EMMA and PCA) and the geochemical pattern-recognition model PIROUETTE to identify and quantify different source waters throughout the freshwater aquifers.

Approach: The investigation will be completed in two distinct phases: (1) Collect and compile new and existing geologic, geochemical, and hydrologic information and define end-member waters from the data using bivariate techniques, and (2) identify saline sources and mixing ratios by using multivariate statistical techniques.

Progress: An interpretive, peer-reviewed report, entitled "Salinity increases in the Navajo aquifer in southeastern Utah," was prepared and accepted by the journal Water Resources Bulletin. A second report, in the form of a USGS Fact Sheet entitled "Using geochemical data to identify sources of salinity to the freshwater Navajo aquifer in southeastern Utah," was prepared and currently is in technical review. Two abstracts describing the study results have been prepared. A technical presentation on the study results received an award by the American Association of Petroleum Geologists. All data collection was completed.

Plans for Next Year: Complete final report, prepare journal article on results of strontium isotopes, publish journal article and Fact Sheet, and give technical presentation on study results at the 1995 American Water Resources Association Spring Symposium. 


\section{National Water Quality Assessment (NAWQA) for Great Salt Lake River Basins,}

Utah, Idaho, and Wyoming

Project Number: UT-94-224

Cooperating Agency: None

Staff: K.M. Waddell, Supervisory Hydrologist, Project Chief

R.L. Baskin, Hydrologist

Period of Project: October 1993-Continuing

Problem: The status and trends of the Nation's water quality have not been evaluated on a consistent basis so that nationwide comparisons can be made.

Objectives: To describe the status and trends of water quality in a nationally consistent manner.

Approach: The Great Salt Lake River Basins study unit was initiated during fiscal year 1994 as one of 69 study units planned for the national study of water quality. The quality of both ground and surface water will be studied by using a nationally consistent approach for design of data collection and methodology for collection and analysis of water samples.

Progress: Completed Fact Sheet, posters, and work-plan documents, and initiated development of data lase for NAWQA study area.

Plans for Next Year: Only partial funding was provided for fiscal year 1995. Planned work is limited to d $c^{\dagger}$ a-base development, some mass-balance calculations, and development of detailed staffing and work plans for fiscal year 1996. 


\section{Scofield-Emery Screening}

Project Number: UT-94-225

Cooperating Agencies: U.S. Department of the Interior National Irrigation Drainage Program, with U.S. Fish and Wildlife Service

\section{Staff: $\quad$ D.W. Stephens, Hydrologist, Project Chief}

\section{Period of Project: October 1994 through September 1995}

Problem: Irrigation drainage from Bureau of Reclamation projects may be causing water-quality problems for some wetlands in the Scofield area and for Desert Lake Waterfowl Management Area.

Objectives: Determine if drainage of agricultural water from the project has caused or is causing problems for human health or fish and wildlife in the two areas.

Approach: Sample water, bottom sediment, and biological tissues from a representative number of sites to determine if wildlife is adversely affected. Determine tissue concentrations of trace elements in wildlife to assess human risk. Sample upstream of Department of the Interior project diversions to determine background levels of contaminants in water and biota.

Progress: Water, bottom sediment, and biota were sampled at 27 sites in the project areas. Analyses were done for most trace elements in all media, and analysis was done for uranium in the water and sediment. All data fcr water analyses have been received as have screening results for bottom sediment. Determination of selenium, arsenic, and mercury in bottom sediment has not been completed, and many bottom sediment samples were destroyed during lab preparation and could not be analyzed. Tissue analyses for the biota have not been completed by U.S. Fish and Wildlife Service laboratories.

Generally, concentrations of most elements in bottom sediments were not sufficiently large to adversely affect biota. Concentrations of selenium in water samples from two subsurface drains were greater than $10 \mu \mathrm{g} / \mathrm{L}$, and water entering Desert Lake Waterfowl Management Area contained as much as $13 \mu \mathrm{g} / \mathrm{L}$. Generally, water containing high concentrations of selenium also contained dissolved uranium in excess of $35 \mu \mathrm{g} / \mathrm{L}$. Data from water testing indicate there are problems with selenium, uranium, and dissolved-solids concentrations in water supplies to Desert Lake. Most water from the Scofield area was generally high in dissolved solids, but selenium concentrations exceeted the State standard of $5 \mu \mathrm{g} / \mathrm{L}$ for wildlife protection only in Coal Creek and Miller Creek.

Plans for Next Year: None. 


\section{Application of Topographically Distributed Energy-Balance Snowmelt-Runoff \\ Model to a Mountain Basin with Cold, Low-Density Snowcover \\ Under Varying Climate Conditions}

Project Number: UT-94-226

Cooperating Agency: Utah Division of Water Rights

Staff: D. Marks, Hydrologist, Project Chief

D.D. Susong, Hydrologist (part time)

Period of Project: October 1994 to September 1997

Problem: Effective management and development of limited water resources in the intermountain western United States is critical to the economic and ecologic well-being of the region. The Central Utah Project (CUP) develops water resources in the Colorado River Basin and Great Basin for delivery to water users along the Wasatcr Range of central Utah. In the areas being developed, most of the precipitation falls as snow. The CUP is an elaborate reservoir and water-distribution system requiring increasingly accurate predictions of snowmelt runoff and stream discharge to optimize reservoir use, maximize water use and availability, and meet water-rights obligations. Current methods for predicting snowmelt and subsequent runoff and stream discharge do not accurately account for topographic controls on snowmelt processes and do not allow water-resource managers to estimate spatial pat ${ }^{+}$erns of snowmelt generation, runoff, and associated effects on water quality, soil moisture, and ground-water recharge. This makes it difficult to optimize reservoir capacities and optimally move water through a complex distribution system under potentially changing land use, land cover, and climate conditions.

Objectives: (1) Design and install a snow and climatic monitoring network to collect data to calibrate the distributed estimates of climate parameters required to drive an energy-balance snowmelt model; (2) develop ar operational version of a topographically distributed energy-balance snowmelt and runoff-routing model that can be used by water-resource managers; (3) test and verify the model using the range of climatic and snowcover conditions that occur in continental mountainous drainages, such as the Wasatch Range of central Utah; (4) modify the energy-balance snowmelt model and its components to be a module within the U.S. Geological Survey Modular Hyc'rologic Modeling System (MHMS); and (5) transfer the technology to water-resource management agencies.

Approach: The energy-balance snowmelt and runoff-routing models will be modified to be a module in MHMS, and the modeling system will be delivered to CUP water managers for operational testing and application. Tre monitoring techniques and models developed in this study will be useful to researchers and water managers in other snow-covered regions. The models will be calibrated to continental snowpacks and will be transferable thrcighout the intermountain region.

Progress: Data collection has begun. A site in the Wasatch Range has been selected, and initial site surveys and monitoring are being done. Geographic-information-system coverages have been created for the Provo and Weber River basins.

Plans for Next Year: Install climate and snow-monitoring equipment at the snow study site. Assemble 1990-94 climate data for modeling. Collect detailed snow data sets. Conduct short-term radiation measurements un ter different vegetation canopies and on different aspects. Publish results of short-term experiments. 
Project Number: UT-94-228

Cooperating Agency: U.S. Environmental Protection Agency

Staff: D.E. Wilberg, Hydrologist, Project Chief

Period of Project: August 1994 to October 1995

Problem: During mining of a sulfide ore deposit to extract valuable minerals and metals, the principal aquifer of the ground-water system of southwestern Salt Lake County has been recharged with water of poor quality. Three sources of the poor-quality water are the Large Bingham Creek Reservoir, the South Jordan Evaporation Pond, and the waste rock, tailings, and abandoned mine tunnels in the Lark area. Low $\mathrm{pH}$ values and increased concentrations of sulfate, trace metals, and dissolved solids characterize the contaminated ground-water system. Kennecott Utah Copper (KUC) is the responsible party and principal investigator of this ground-water contamination study, which qualifies for the National Priority List but has not been listed.

Objectives: Recently, the U.S. Environmental Protection Agency (EPA) and KUC agreed to do a Remedial Investigation/Feasibility Study (RI/FS) to characterize site conditions and evaluate remedial alternatives. At the request of the EPA and with the consensus of members of a technical review committee, the U.S. Geological Survey agreed to serve as technical advisor to the EPA and oversee the RI/FS activities done by KUC in their efforts to chara-terize, delineate the extent of, and remediate the contaminated ground water.

Approach: As technical advisor, U.S. Geological Survey personnel with appropriate expertise will review and critique documents, workplans, and operating procedures when required. Consultation with appropriate persc nnel of the U.S. Geological Survey, both locally and nationally, will occur as the need arises.

KUC currently is drilling holes in excess of 1,000 feet deep for installation of up to three monitoring wells for hole that will be completed at different depths in and below the intervals of poor-quality water. Information obtained by KUC and their contractors during the drilling and installation of monitoring wells and from analysis of water samples collected from the monitoring wells will allow characterization and delineation of the poor-quality ground water. The U.S. Geological Survey will periodically observe these activities to ensure adherence to KUC standard operating procedures and to collect duplicate water samples for analysis at the U.S. Geological Survey National Water Quality Laboratory or at other laboratories. Comparison of analytical results will provide a basis to either corroborate the veracity of KUC findings or, if the results are different, to determine what the problem is and seek a solution. A concept of "tiered" oversight by the U.S. Geological Survey will be contingent on the nature of a potential problem. For example, if a discrepancy between analyses is determined, then the number of duplicate samples will increase until the problem is resolved to the satisfaction of all entities involved. Conversely, if it is determired that no analysis problem exists, then the U.S. Geological Survey will collect duplicate samples from selected wells at a less frequent interval yet to be determined. Ground-water and transport-modeling activities by the U.S. Gec'ogical Survey might be developed in the future.

Progress: Reviewed RI/FS workplan written by Kennecott consultants and met with them for discussion. Ccllected split samples at selected wells to do quality-control check on Kennecott Laboratory. Submitted quarterly report to the EPA.

Plans for Next Year: Continue providing technical expertise during each phase of remediation. Monitor implementation of work plan and help guide the work through onsite visits and review of work component descriptions. Help plan modeling phase of project. Offer technical review of workplan for the EPA. 
Recharge Areas and Ground-Water Quality in Tooele Valley, Utah

Project Number: UT-94-229

Cooperating Agencies: Tooele County, Utah Geological Survey, Utah Department of Environmental Quality, Utah Division of Water Rights

\section{Staff: J. Steiger, Hydrologist, Project Chief}

Period of Project: August 1994 to September 1995

Problem: Tooele County is experiencing rapid population growth in its rural areas. Much of the population growth is in areas where sewage-treatment facilities are not available and septic tanks are used. A potential problem associated with disposing sewage in a large number of septic tanks is increased nitrate concentrations in ground water. To protect ground-water resources, Tooele County Commissioners would like to classify their ground-water system, establish ground-water protection levels, and regulate existing and potential sources of contamination. This project is designed to provide some of the information needed by Tooele County for classifying the ground-water system in Tooele Valley.

Objectives: The objectives of this study are to provide Tooele County with (1) a map showing primary and secondary ground-water recharge areas and the discharge areas; (2) a map showing dissolved-solids concentrations in water from wells less than about 150 feet deep and in wells equal to or greater than about 150 feet deep; and (3) a table showing water quality in selected wells in Tooele Valley.

Approach: The first phase of the project involves mapping primary and secondary recharge areas and discharge areas based on information contained in drillers' logs, water-level measurements, and on location of spring $?$ flowing wells, and phreatophytes.

The second phase will document past and present water quality. Ground-water samples for chemical analysis from about 50 sites will be collected. The results of the analyses will be combined with existing data in a table showing water quality in water samples from wells and springs. This information will be used to identify areas where dissolved-solids concentrations are less than 500 milligrams per liter $(\mathrm{mg} / \mathrm{L}), 500$ to 3,000 mg/L, 3,000 to $10,000 \mathrm{mg} / \mathrm{L}$, and greater than $10,000 \mathrm{mg} / \mathrm{L}$. The third phase of the project will incorporate the data and data analysis into a map report.

Progress: Coverages for a base map were created and editing was started. Well logs were compiled for selection of water-quality sampling sites. Well inventory was started.

Plans for Next Year: Complete all data collection, compilation, and analysis. Prepare map report and sut mit for review and approval.

\section{References cited}

Lines, G.C., 1979, Hydrology and surface morphology of the Bonneville Salt Flats and Pilot Valley Playa, Utah: U.S. Geological Survey Water-Supply Paper 2057, 107 p. 